\title{
Time-Resolved Molecular Characterization of Organic Aerosols by PILS + UPLC/ESI-Q-TOFMS
}

\author{
X. Zhang ${ }^{1}$, N. F. Dalleska ${ }^{1}$, D. D. Huang ${ }^{3}$, K. H. Bates ${ }^{2}$,
}

A. Sorooshian ${ }^{4}$, R. C. Flagan ${ }^{1,2}$, and J. H. Seinfeld ${ }^{1,2, *}$

${ }^{1}$ Division of Engineering and Applied Science, California Institute of Technology, Pasadena, CA, USA

${ }^{2}$ Division of Chemistry and Chemical Engineering, California Institute of Technology, Pasadena, CA, USA

${ }^{3}$ Department of Chemical and Biomolecular Engineering, Hong Kong University of Science and Technology, Hong Kong, China

${ }^{4}$ Department of Chemical and Environmental Engineering/Atmospheric Sciences, The University of Arizona, Arizona, USA

\section{${ }^{*}$ Corresponding Author}

Email address: seinfeld@caltech.edu (J. H. Seinfeld) 


\begin{abstract}
Real-time and quantitative measurement of particulate matter chemical composition represents one of the most challenging problems in the field of atmospheric chemistry. In the present study, we integrate the Particle-into-Liquid Sampler (PILS) with Ultra Performance Liquid Chromatography / Electrospray ionization Quadrupole Time-ofFlight High-Resolution / Mass Spectrometry (UPLC/ESI-Q-TOFMS) for the timeresolved molecular speciation of chamber-derived secondary organic aerosol (SOA). The unique aspect of the combination of these two well-proven techniques is to provide quantifiable molecular-level information of particle-phase organic compounds on timescales of minutes. We demonstrate that the application of the PILS + UPLC/ESI-QTOFMS method is not limited to water-soluble inorganic ions and organic carbon, but is extended to slightly water-soluble species through collection efficiency calibration together with sensitivity and linearity tests. By correlating the water solubility of individual species with their O:C ratio, a parameter that is available for aerosol ensembles as well, we define an average aerosol O:C ratio threshold of 0.3, above which the PILS overall particulate mass collection efficiency approaches $\sim 0.7$. The PILS + UPLC/ESIQ-TOFMS method can be potentially applied to probe the formation and evolution mechanism of a variety of biogenic and anthropogenic SOA systems in laboratory chamber experiments. We illustrate the application of this method to the reactive uptake of isoprene epoxydiols (IEPOX) on hydrated and acidic ammonium sulfate aerosols.
\end{abstract}




\section{Introduction}

Chemical characterization of particulate organic compounds is crucial to understand the formation and evolution of secondary organic aerosol (SOA). The conventional method for particle-phase molecular speciation is to collect aerosols on a filter substrate, followed by extraction and preconcentration. Analysis of filter extracts is commonly performed by liquid chromatography (LC) and gas chromatography (GC), coupled to mass spectrometry with the use of electron ionization (EI), chemical ionization (CI), electrospray ionization (ESI), and atmospheric pressure chemical ionization (APCI) (Dye and Yttri, 2005; Simpson et al., 2005; Surratt et al., 2006 and 2007 a, b; Lavrich and Hays, 2007; Szmigielski et al., 2007; Lin et al., 2012). Major organic classes in SOA that have been identified from filter-based analysis include (nitrooxy)-organosulfates (Surratt et al., 2007 a, b and 2008; Iinuma et al., 2007; Chan et al., 2011), dimers, trimers, and oligomers (Jang et al., 2002; Limbeck et al., 2003; Gao et al., 2004; Kalberer et al., 2004; Fahnestock et al., 2014), and humic-like substances (Gelencsér et al., 2002; Graham et al., 2002). A limitation of filter-based analysis is low time resolution and, consequently, the inability to track particle-phase kinetics. In addition, filter artifacts, such as adsorption of ambient vapors and evaporation of semi-volatile compounds from the filter surface, lead to uncertainties in the quantification of particle-phase components (Turpin et al., 2000; Schauer et al., 2003; Dzepina et al., 2007).

Powerful, on-line techniques have been developed for chemical speciation of organic aerosols, with rapid time response and minimum sample handling. The general principle is to vaporize airborne aerosols by thermal or laser desorption, followed by ionization and mass spectrometric detection (Sullivan and Prather, 2005; Canagaratna et al., 2007). The Aerodyne Aerosol Mass Spectrometer (AMS), which is now a routine component of ambient and chamber studies, enables measurement of organic fragments and derivation of the atomic O:C and H:C ratios (Jimenez et al., 2003; Aiken et al., 2007, 2008). Identification of individual species by AMS is not available due to the high evaporation temperature $\left(600{ }^{\circ} \mathrm{C}\right)$ and EI energy $(70 \mathrm{eV})$, which result in significant molecular fragmentation. Moreover, all thermal/laser desorption methods are susceptible to fragmentation of non-refractory compounds. To achieve unambiguous molecular identification of particulate organic compounds, extensive fragmentation is avoided by 
employing soft ionization techniques such as chemical ionization (Hoffmann et al., 1998; Hearn and Smith, 2004; Smith et al., 2005; Hellén et al., 2008; Yatavelli and Thornton, 2010; Aljawhary, et al., 2013; Lopez-Hilfiker, et al., 2014), photoelectron resonance capture ionization (LaFranchi and Petrucci, 2006; Zahardis et al., 2006), and vacuum ultraviolet single photon ionization (Öktem et al., 2004; Ferge et al., 2005; Northway et al., 2007; Isaacman et al., 2012; Chan et al., 2013). Full-scale implementation of these methods into routine measurements requires achieving short measurement cycles, resolving quantification capability, interpreting the mass spectral complexity, and comparing data recovery with conventional methods.

The Particle-into-Liquid Sampler (PILS), first developed by Weber et al. (2001), grows aerosols by supersaturated water vapor condensation, producing droplets sufficiently large for collection by inertial impaction. The resulting liquid samples can be analyzed by ion chromatography (IC) for water-soluble inorganic ions and small dicarboxylic acids (Orsini et al., 2003; Ma et al., 2004; Sorooshian et al., 2007, 2008), or by a total organic carbon analyzer (TOC) for the total water soluble organic carbon (WSOC) (Sullivan et al., 2006; Peltier et al., 2007). PILS coupled with mass spectrometry has also been deployed for the analysis of WSOC in field and chamber measurements. Bateman et al. (2010) compared the off-line mass spectra of limonene $+\mathrm{O}_{3}$ derived SOA samples collected by PILS with those collected on filter substrates and found that the peak abundance, organic mass to organic carbon ratios, and the average $\mathrm{O}: \mathrm{C}$ ratio are essentially identical. Parshintsev et al. (2010) integrated PILS on-line with a solid-phase extraction chromatographic system for the characterization of organic acids. Using a similar concept, Clark et al. (2013) directly injected PILS samples into the ionization source of the mass spectrometer and validated the PILS-ToF-MS system against other particle measurement methods in terms of total ion abundance and average $\mathrm{O}: \mathrm{C}$ ratios of isoprene and $\alpha$-pinene derived SOA.

A primary challenge in the deployment of PILS as an effective particle collection device lies in the determination of the overall mass collection efficiency. Ambient and chamber derived organic aerosols usually comprise of thousands of species with various physicochemical properties. Since PILS was originally designed to use water steam as 
the growing agent, one expects that particles with an extreme hydrophobic surface would be difficult to collect. Therefore, a guideline needs to be developed for the reference of PILS selectivity to certain types of aerosols. This is one main focus of the present study.

Here we combine PILS with Ultra Performance Liquid Chromatography / Electrospray Ionization Quadrupole Time-of-Flight High-Resolution Mass Spectrometry (UPLC/ESIQ-TOFMS), for time-revolved molecular-level characterization of SOA during chamber experiments. This technique is particularly suited to polar or water-soluble organic molecules, and potentially high molecular weight species, such as organosulfates. Advantages of this technique include: 1) No need for sample preparation; 2) Molecularlevel information can be inferred from the electrospray ionization process, in which ions are, in general, observed as those of the parent molecule with the addition of an $\mathrm{H}$ atom (positive mode) or removal of an $\mathrm{H}$ atom (negative mode); 3) Temporal profiles of particle composition can be obtained on a time scale consistent with that of SOA evolution; and 4) Chromatographic separation of organic compounds with different polarities avoids the analyte signal suppression that occurs during the electrospray

process of organic mixtures, leading to molecular-level quantification of particle-phase constituents. We demonstrate that the PILS+ UPLC/ESI-Q-TOFMS method is suitable to measure water-soluble organic carbon (WSOC), as well as less hydrophilic or slightly water-soluble compounds. A collection efficiency of $>0.6$ can be achieved for chamberderived SOA systems with average $\mathrm{O}: \mathrm{C}$ ratios $>0.3$. We illustrate the application of this technique to the reactive uptake of isoprene epoxydiols (IEPOX) on hydrated and acidic ammonium sulfate aerosols.

\section{Method description}

\subsection{Pure component organic aerosols}

Table 1 gives the chemical properties of organic standards (purchased from Sigma Aldrich) that were used to generate pure component organic aerosols. These standards include carboxylic acids, amines, and polyols that span a broad range in water solubility from miscible to insoluble, and vapor pressure from intermediate to low volatility. Each standard was dissolved in water or isopropanol to produce a concentrated solution. 
Aerosols with known chemical composition were produced by atomizing each single concentrated solution followed by desolvation. Two diffusion denuders filled with silica gel and activated carbon were used to remove the solvent prior to injection into the Caltech $24 \mathrm{~m}^{3}$ Teflon chamber. Relative humidity (RH) and temperature in the chamber were maintained at $<5 \%$ and $25{ }^{\circ} \mathrm{C}$, respectively. The size distribution and number concentration of the pure component organic aerosols were measured continuously using a custom-built scanning mobility particle sizer (SMPS) consisting of a differential mobility analyzer (DMA, TSI, 3081) coupled with a condensation particle counter (CPC, TSI, 3010). More details of the SMPS operation can be found in Loza et al. (2014) and Zhang et al. (2014 a, b).

\subsection{Particle-into-Liquid Sampler (PILS)}

Detailed characterization of the Caltech PILS, which is based on a modification of the original design of Weber et al. (2001), is described by Sorooshian et al. (2006). The chamber aerosol is sampled through a $1 \mu \mathrm{m}$ cut size impactor with a flow rate of $12.5 \mathrm{~L}$ $\min ^{-1}$, and passed successively through individual acid and base gas denuders and an organic carbon denuder to remove inorganic and organic vapors. A steam flow generated at $100{ }^{\circ} \mathrm{C}$ is adiabatically mixed with the cooler sampled air in a condensation chamber, creating a high water supersaturation environment in which particles grow sufficiently large $\left(D_{\mathrm{p}}>1 \mu \mathrm{m}\right)$ for collection by inertial impaction onto a quartz plate. Impacted particles are transported to a debubbler by a washing flow $\left(0.15 \mathrm{~mL} \mathrm{~min}{ }^{-1}\right)$ comprising $50 \%$ water and $50 \%$ isopropanol. The sampled liquid is delivered into vials held on a rotating carousel. This design is especially beneficial for the application of liquid chromatography for organic compound separation and selection, which generally requires a longer time than the PILS collection cycle. Under the current configuration, a 5-min time resolution can be achieved for the characterization of particle-phase dynamics.

2.3 Ultra Performance Liquid Chromatography / Electrospray ionization Quadrupole Time-of-Flight High-Resolution / Mass Spectrometry (UPLC/ESI-Q-TOFMS) 
The PILS collected samples are stored at $4{ }^{\circ} \mathrm{C}$ and analyzed by UPLC/ESI-Q-TOFMS within $24 \mathrm{~h}$ without further pretreatment. A WATERS ACQUITY UPLC I-Class System, coupled with a Quadrupole Time-of-flight Mass Spectrometer (Xevo G2-S QToF) and equipped with an electrospray ionization (ESI) source, was used to identify and quantify the PILS collected samples, including organic aerosol standards and chamber generated SOA. An ACUITY BEH $\mathrm{C}_{18}$ column $(2.1 \times 50 \mathrm{~mm})$ was used to separate relatively nonpolar species, including vanillic acid, azelaic acid, cis-pinonic acid, myristic acid, palmitic acid, and IEPOX-derived SOA. The eluent program is: $0-3.2$ min: $100 \% \mathrm{~A}$ ( $0.1 \%$ formic acid in water); $3.2-3.5 \mathrm{~min}: 10 \% \mathrm{~A}$ and $90 \% \mathrm{~B}$ (acetonitrile); $3.5-5 \mathrm{~min}$ : $100 \% \mathrm{~A}$. The total flow rate is $0.5 \mathrm{~mL} \mathrm{~min} \mathrm{~m}^{-1}$ and the injection volume is $5 \mu \mathrm{L}$. For extremely polar or water soluble compounds, including adenine, adonitol, adipic acid, dsorbitol and diethylmalonic acid, an ACUITY BEH Amide column $(2.1 \times 150 \mathrm{~mm})$ was used for species separation. The eluent program is: $0-3 \mathrm{~min}$ : 5\% A (10 $\mathrm{mM}$ ammonium formate in water at $\mathrm{pH}=9$ ) and 95\% B (acetonitrile); $3-3.01 \mathrm{~min}$ : 45\% A and 55\% B; $3.01-8 \mathrm{~min}: 5 \% \mathrm{~A}$ and $95 \% \mathrm{~B}$. The total flow rate is $0.6 \mathrm{~mL} \mathrm{~min}^{-1}$ and the injection volume is $4 \mu \mathrm{L}$. Note that the eluent program used here is customized for the characterization of test aerosols that are composed of a single chemical standard. For chamber-derived SOA samples that might contain thousands of species with a variety of polarities, key parameters of the eluent program, such as the type and ratio of polar vs. nonpolar solvents, the additives and $\mathrm{pH}$ range in the mobile phase, and the overall elution duration, need to be optimized to achieve compound specificity. The choice of separation modes is also very important. For extremely polar compounds, hydrophilic-interaction chromatography is a more suitable approach, compared with reverse-phase chromatography, which has been, though, widely used in particle-phase speciation in previous studies. Optimum electrospray conditions are: $2.0 \mathrm{kV}$ capillary voltage, $40 \mathrm{~V}$ sampling cone, $30 \mathrm{~V}$ source offset, $120{ }^{\circ} \mathrm{C}$ source temperature, $350{ }^{\circ} \mathrm{C}$ desolvation temperature, $30 \mathrm{~L} \mathrm{~h}^{-1}$ cone gas, and $650 \mathrm{~L} \mathrm{~h}^{-1}$ desolvation gas. MS/MS spectra were obtained by applying a collision energy ramping program starting from $15 \mathrm{eV}$ to $50 \mathrm{eV}$ over one MS scan in the collision cell. Accurate masses were corrected by a lock spray of 
leucine encephalin $\left(\mathrm{m} / z 556.2771[\mathrm{M}+\mathrm{H}]^{+}\right)$. Data were acquired and processed using the MassLynx v4.1 software.

\section{Method evaluation}

3.1 Simulation of hygroscopic growth of organic aerosols

The operational principle of the PILS is to grow particles in the presence of supersaturated water vapor to the size of micro-droplets that can be collected by inertial impaction. A key parameter that governs the extent of particle growth is the water accommodation coefficient $\left(\alpha_{\mathrm{w}}\right)$, which is defined as the fraction of water molecules that are taken up by the particles upon collision with the surface. Here we investigate numerically the influence of $\alpha_{w}$ on the predicted final size of the droplets by condensational growth of particles.

The growth of a particle of diameter $D_{\mathrm{p}}$ in the presence of supersaturated water vapor is governed by (Seinfeld and Pandis, 2006):

$$
\frac{d D_{\mathrm{p}}}{d t}=\frac{4 \mathcal{D}_{\mathrm{w}} M_{\mathrm{w}}}{R T D_{\mathrm{p}} \rho_{\mathrm{p}}}\left[p_{\mathrm{w}}^{\infty}-p_{\mathrm{w}}^{\mathrm{s}}\left(D_{\mathrm{p}}, T_{\mathrm{s}}\right)\right] f\left(K n, \alpha_{\mathrm{w}}\right)
$$

where $\mathcal{D}_{\mathrm{w}}$ is the water vapor diffusivity, $M_{\mathrm{w}}$ is the water molecular weight, $R$ is the gas constant, $T$ is the temperature, $\rho_{\mathrm{p}}$ is the particle density, $K n\left(=2 \lambda / D_{\mathrm{p}}\right)$ is the Knudsen number, $f\left(K n, \alpha_{\mathrm{w}}\right)$ is the correction factor for noncontinuum conditions and imperfect accommodation, $p_{\mathrm{w}}^{\infty}$ is the water saturation vapor pressure far from the particle, and $p_{\mathrm{w}}^{\mathrm{s}}\left(D_{\mathrm{p}}, T_{\mathrm{s}}\right)$ is the water vapor pressure over the particle surface. Taking into account the vapor pressure variation due to the Kelvin effect, $p_{\mathrm{w}}^{\mathrm{s}}\left(D_{\mathrm{p}}, T_{\mathrm{s}}\right)$ becomes:

$$
p_{\mathrm{w}}^{\mathrm{s}}\left(D_{\mathrm{p}}, T_{\mathrm{s}}\right)=p_{\mathrm{w}}^{0}\left(T_{\mathrm{s}}\right) \chi_{\mathrm{w}} \gamma_{\mathrm{w}} \exp \left(\frac{4 \sigma v_{1}}{R T D_{\mathrm{p}}}\right)
$$

where $p_{\mathrm{w}}^{0}\left(T_{\mathrm{s}}\right)$ is the water saturation vapor pressure at the particle temperature $T_{\mathrm{s}}, \chi_{\mathrm{w}}$ is the mole fraction of water in the particle phase, $\sigma$ is the water surface tension, $v_{1}$ is the water molar volume, and $\gamma_{\mathrm{w}}$ is the water activity coefficient, which is assumed to be unity here. Note that particles in the PILS condensation chamber are assumed to behave as a 
dilute solution so that $\gamma_{\mathrm{w}}$ approaches its infinite dilution limit $\gamma_{\mathrm{w}} \rightarrow 1$. This is reasonable considering that the water volume fraction exceeds 0.93 in particles after $0.1 \mathrm{~s}$ of hygroscopic growth. The water activity coefficient deviates from unity $(<1)$ in non-ideal organic-salt-water mixtures (Zuend et al., 2008, 2010), which is the case during the initial particle growth stage in the PILS condensation chamber. This leads to an overestimate of the water vapor partial pressure over the particle surface, and consequently, slower simulated particle growth rate due to water condensation. In other words, the actual particle hydroscopic growth rate in the PILS condensation chamber should be faster than the model simulations.

The particle surface temperature is determined by an energy balance on the particle (Seinfeld and Pandis, 2006):

$$
\Delta T=\frac{\Delta H_{\mathrm{v}} \mathcal{D}_{\mathrm{w}} \rho_{\mathrm{w}}}{k_{\mathrm{a}}^{\prime} T_{\infty}}\left[S_{\mathrm{w}, \infty}-\exp \left(\frac{\Delta H_{\mathrm{v}} M_{\mathrm{w}}}{R T_{\infty}} \frac{\Delta T}{1+\Delta T}+\frac{4 \sigma v_{1}}{R T D_{\mathrm{p}}}\right)\right] f(K n, \alpha)
$$

where $\Delta T=\left(T_{\mathrm{s}}-T_{\infty}\right) / T_{\infty}, \Delta H_{\mathrm{v}}$ is the latent heat of vaporization of water, $\rho_{\mathrm{w}}$ is the density of water steam, $k_{\mathrm{a}}^{\prime}$ is the effective thermal conductivity of air corrected for noncontinuum effects, and $S_{\mathrm{w}, \infty}=p_{\mathrm{w}}^{\infty} / p_{\mathrm{w}}^{0}\left(T_{\infty}\right)$ is the environmental saturation ratio. Equation (3) needs to be solved numerically to determine the particle surface temperature that is required in the calculation of the particle growth rate.

Figure 1 shows the predicted hygroscopic growth of particles, with initial diameters ranging from $20 \mathrm{~nm}$ to $800 \mathrm{~nm}$, as a function of water accommodation coefficient $\left(\alpha_{\mathrm{w}}\right)$. Particles with highly hydrophilic surface composition $\left(\alpha_{\mathrm{w}} \rightarrow 1\right)$ can grow sufficiently large $\left(D_{\mathrm{p}}>1 \mu \mathrm{m}\right)$ to be collected by inertial impaction within $1 \mathrm{~s}$, the particle residence time in the PILS condensation chamber. Water vapor mass transfer to less hydrophilic particles $\left(\alpha_{\mathrm{w}} \geq 10^{-2}\right)$ is still sufficiently rapid to grow particles to droplets $>1 \mu \mathrm{m}$ size. Significant kinetic reductions in water uptake result when the particle-phase constituents are strongly hydrophobic $\left(\alpha_{\mathrm{w}} \leq 10^{-3}\right)$. The effect of initial relative humidity (RH) in aerosol sampling flow on the ultimate droplet size becomes critical when $\alpha_{\mathrm{w}}$ is $\sim 10^{-3}$. The simulations suggest that PILS can potentially collect particles with a wide range of water solubility, due to the substantial imbalance in water vapor abundance far from and 
over the particle surface. As discussed earlier, the assumption of ideal water-ion-organic interactions leads to the underestimation of particle hygroscopic growth rate. As a result, the specification of $\alpha_{\mathrm{w}}$ in the order of $\sim 10^{-3}$ as a criterion for 'hydrophobic' particles that fail to grow over $1 \mu \mathrm{m}$ diameter might be a bit conservative.

\subsection{Collection efficiency}

The PILS collection efficiency may deviate from unity owing to three processes: 1) particle losses due to gravitational settling, diffusion, and inertial deposition during transport in the PILS plumbing system and condensation chamber, 2) evaporation of semi-volatile components during adiabatic mixing with steam, and 3) imperfect accommodation of water vapor on particles, if hydrophobic (Weber et al., 2010; Orsini et al., 2003; Sorooshian et al., 2006). In the present study, we characterize the PILS collection efficiency by varying the particle chemical composition (i.e., polarity and volatility) and size distribution. The overall mass collection efficiency $\left(C E_{\mathrm{PILS}}\right)$ can be obtained by comparing the mass concentration measured by the UPLC/ESI-Q-TOFMS and that derived from the DMA measured particle volume distribution, assuming particle sphericity (Sorooshian et al., 2006),

$$
C E_{\mathrm{PILS}}=\frac{1000 \cdot m \cdot Q_{1} \cdot D F \cdot \rho_{1}}{Q_{\mathrm{g}} \cdot \rho_{\mathrm{p}} \cdot V_{\mathrm{p}}}
$$

where 1000 is the unit conversion factor, $m$ is the UPLC/ESI-Q-TOFMS measured organic standard mixing ratio (ppm), $Q_{1}$ is the liquid sampling flow rate $\left(1.5 \mathrm{~mL} \mathrm{~min}{ }^{-1}\right)$, $D F$ is the dilution factor that accounts for the water vapor condensation on the impactor wall and air bubbles during the filling of vials, $\rho_{1}$ is the density of collected liquid, which is assumed as the density of the washing flow $\left(0.893 \mathrm{~g} \mathrm{~cm}^{-3}\right), Q_{\mathrm{g}}$ is the gas sampling flow rate $\left(12.5 \mathrm{~L} \mathrm{~min}^{-1}\right), V_{\mathrm{p}}$ is the particle total volume concentration $\left(\mu \mathrm{m}^{3} \mathrm{~cm}^{-3}\right)$ derived from the DMA measured number distribution, and $\rho_{\mathrm{p}}$ is the particle density $\left(\mathrm{g} \mathrm{cm}^{-3}\right)$. Note that $\rho_{\mathrm{p}}$ here is assumed as the density of corresponding chemical standards that are used to generate test aerosols. For chamber-derived SOA, $\rho_{\mathrm{p}}$ can be derived from the AMS measured O:C and H:C ratios (Kuwata et al., 2012). A 5-min offset in the PILS 
measurement is taken into account to retrieve the particle concentration at the moment of entry into the PILS inlet.

Figure 2 shows the measured PILS mass collection efficiency ( $\left.C E_{\mathrm{PILS}}\right)$ as a function of particle water solubility and volatility. Consistent with the model prediction, the high collection efficiency in the PILS is achieved not only for highly water soluble and nonvolatile aerosols such as sorbitol, but also for slightly water soluble and intermediate/semi-volatile aerosols such as pinonic acid. The water solubility of particlephase constituents clearly governs $C E_{\mathrm{PILS}}$. The effect of volatility on $C E_{\mathrm{PILS}}$, however, is not discernable, indicating that the evaporation of semi-volatiles from particles during adiabatic mixing with steam is negligible for compounds with vapor pressure $<10^{-6} \mathrm{~atm}$. We define the particle water solubility threshold of $1 \mathrm{~g} \mathrm{~L}^{-1}$ above which $>0.6$ mass collection efficiency can be achieved. Considering that SOA water solubility data are generally unavailable, this quantity can be related to the average particle $\mathrm{O}: \mathrm{C}$ ratio, which is relatively well constrained by the AMS measurement.

Figure 3 shows the water solubilities (the maximum amount of the compound $i$ that will dissolve in pure water at $20{ }^{\circ} \mathrm{C}$ on the logarithm scale, $\log _{10} \mathrm{H}_{\mathrm{i}} / \mathrm{g} \mathrm{L}^{-1}$ ) of a variety of organic compounds, including carboxylic acids, alcohols, carbonyls, esters, and ethers, as a function of their $\mathrm{O}: \mathrm{C}$ ratios. Regardless of the nature of functionalities in the molecule, the water solubility increases with the $\mathrm{O}: \mathrm{C}$ ratio and eventually reaches a plateau, a miscible state with water. The $\mathrm{O}: \mathrm{C}$ ratio corresponding to the water solubility threshold of $1 \mathrm{~g} \mathrm{~L}^{-1}$ varies with functionalities, ranging from 0.07 to 0.26 . Considering that SOA is generally a mixture of species that might contain all the functional groups above, we suggest that the upper limit of the $\mathrm{O}: \mathrm{C}$ ratio, 0.26 , represents a criterion to constrain an effective PILS mass collection efficiency. The AMS measured O:C ratios for SOA produced from isoprene $+\mathrm{OH}, \alpha$-pinene $+\mathrm{O}_{3} / \mathrm{OH}$, aromatics $+\mathrm{OH}$, and $\mathrm{C}_{12}$-alkane $+\mathrm{OH}$ in the Caltech Environmental Chamber have been summarized previously (Chhabra et al., 2010, 2011; Zhang and Seinfeld, 2013; Loza et al., 2014). Among all the systems investigated, long-chain alkane derived SOA exhibits the lowest $\mathrm{O}: \mathrm{C}$ ratio, ranging from $\sim 0.2$ to $\sim 0.3$, over the course of $3-36 \mathrm{~h}$ experiments $\left([\mathrm{OH}]_{\text {exposure }} \cong 2-8\right.$ molecules $\mathrm{cm}^{-}$

${ }^{3} \mathrm{~h}$ ). The average $\mathrm{O}: \mathrm{C}$ ratios measured from other SOA systems, on the other hand, 
exceed the threshold, 0.26, at which $>0.6$ mass collection efficiency by PILS can be achieved. Thus, PILS is a candidate as a high efficiency, time-resolved particle collection method for a majority of SOA systems.

Particles are subject to gravitational settling, diffusion, and inertial deposition in the PILS plumbing system and condensation chamber. The largest losses occur for small ( $D_{\mathrm{p}}$ $<10 \mathrm{~nm}$ ) and large particles $\left(D_{\mathrm{p}}>1000 \mathrm{~nm}\right)$, as predicted to be $2.2 \%$ and $8.6 \%$, respectively (Sorooshian et al., 2006). Considering that the PILS transmission efficiency (defined as the fraction of particles of a certain size that are transported through the PILS plumbing system and condensation chamber) depends strongly on the particle size, the impact of variations in the particle size distribution on the PILS overall mass collection efficiency ( $\left.C E_{\text {PILS }}\right)$ is at issue. For a typical SOA chamber experiment, the initial size distribution of seed particles spans from $\sim 20 \mathrm{~nm}$ to $\sim 600 \mathrm{~nm}$, with a median diameter of $\sim 60-70 \mathrm{~nm}$. Growth driven by gas-phase photochemistry and gas-particle partitioning occurs primarily on large particles and, as a result, the number median diameter shifts to $\sim 200 \mathrm{~nm}$ after $\sim 20 \mathrm{~h}$ of irradiation. To mimic the progression of the particle size distribution during SOA formation, test particles were initially generated by atomizing concentrated pinonic acid solution into the chamber. An external flow pulse creates intense turbulent mixing in the chamber. As a result, the median diameter of the cispinonic acid particles shifted from $\sim 90 \mathrm{~nm}$ to $\sim 200 \mathrm{~nm}$ during the $3.5 \mathrm{~h}$ experiment, due to rapid deposition of the smaller particles onto the chamber wall, see Fig. 4. The overall PILS mass collection efficiency, on the other hand, remains consistently close to unity, within $\sim 8 \%$ uncertainty. This test demonstrates that change in particle size distribution during SOA formation and evolution under typical chamber experimental conditions does not significantly impact the PILS collection efficiency.

\subsection{Sensitivity, detection limit, and uncertainties}

The extent of linearity of UPLC/ESI-Q-TOFMS detected signals for PILS collected organic aerosols was examined in response to changes in particle mass loadings. Sorbitol, azelaic acid, pinonic acid, and adipic acid aerosols, with mass concentrations ranging from $20-300 \mu \mathrm{g} \mathrm{m}^{-3}$, were generated by varying the atomization and dilution duration. 
Mass concentrations of these four organic aerosol standards were derived from the SMPS measured particle volume distribution. The UPLC/ESI-Q-TOFMS signals for sorbitol, azelaic acid, and pinonic acid, as shown in Fig. 5, exhibit linearity $\left(\mathrm{R}^{2}=0.99\right)$ with organic mass loadings. The sensitivity for adipic acid, however, is drifting low when particle concentrations are diluted, and as a result, there is a strong negative offset in the linear fitting curve. The low sensitivity for adipic acid might be attributed to the slight solubility of adipic acid dimer, which is the dominant particle-phase form of adipic acid (Wolfs and Desseyn, 1996).

The detection limit of the PILS + UPLC/ESI-Q-TOFMS system can be estimated from the expected UPLC/ESI-Q-TOFMS sensitivity and measured flow rates of sampling air and liquid washing stream. The UPLC/ESI-Q-TOFMS detection limit (LOD) was calculated according to the expression:

$$
\frac{S}{N}=\frac{k_{i} \cdot L O D}{\sigma}
$$

where $S / N$ is the signal-to-noise ratio, $k_{i}$ is the response factor or the sensitivity of UPLC/ESI-Q-TOFMS for species $i$, and $\sigma$ is the standard deviation of the response. Using a signal-to-noise ratio of 2 , LOD of $0.68 \mathrm{ppb}$ is obtained for cis-pinonic acid as an example. With a gas flow rate of $12.5 \mathrm{~L} \mathrm{~min}^{-1}$, and a washing flow rate of $0.15 \mathrm{~mL} \mathrm{~min}^{-1}$, the PILS + UPLC/ESI-Q-TOFMS system is estimated to have a detection limit of 19.02 $\mathrm{ng} \mathrm{m}^{-3}$ for $c i s$-pinonic acid in the particle phase. By analogy with other compounds that are selected by UPLC, the sensitivity of the Q-TOFMS technology can be practically achieved as low as $\sim$ ppb level. Thus we expect the detection limit of PILS + UPLC/ESIQ-TOFMS measurement of the mass of particle components in the range of tens of $\mathrm{ng} \mathrm{m}^{-}$

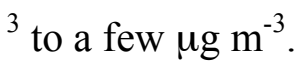

Uncertainties in the PILS + UPLC/ESI-Q-TOFMS measurement arise mainly from variation of the collected liquid volume due to the existence of air bubbles. Specifically, the washing flow carries the impacted droplets via a stainless steel mesh wick on the perimeter of the impactor to a 'T-shape' debubbler. Air bubbles are vacuumed out of the system by a peristaltic pump. The liquids are delivered into the injection needle that is inserted into individual vials by two syringe pumps. Perfect debubbling cannot always be 
achieved and as a result, the collected liquid volumes in some vials can drift low. The measurement uncertainties due to the existence of air bubbles in the liquid samples are estimated to be $<11 \%$ by weighing a batch of vials over one carousel running cycle (72 vials). Repeatability in the detected yield of ions from the electrospray ionization of the analyte is another potential origin of measurement uncertainties. This was estimated to be $<3 \%$ by repeating injection of $4 \mu \mathrm{L}$ standard organic samples into the electrospray source. The effect of ESI-MS sensitivity drift on the measurement accuracy is accounted for by regularly performing the repeatability of organic standards (one standard every ten samples) during routine sample analysis.

While the PILS + UPLC/ESI-Q-TOFMS system is demonstrated to achieve timeresolved molecular speciation of secondary organic aerosols, we acknowledge the potential artifacts and uncertainties arising from aerosol sampling and analysis

procedures. First, the hydrolysis of labile functionalities, mainly including organic nitrates, carbonyls, and epoxides, upon solvation is inevitable in any aerosol collection, pretreatment and analysis procedures using water as the solvent. Second, water steam $\left(100 \pm 2{ }^{\circ} \mathrm{C}\right)$ is mixed with aerosol sample flow $\left(25 \pm 5^{\circ} \mathrm{C}\right)$ in the PILS condensation chamber, with temperature eventually stabilized as $\sim 36^{\circ} \mathrm{C}$. During mixing, organic aerosol constituents are subjected to evaporation and thermal decomposition. We have demonstrated earlier that the evaporation of semivolatile organic compounds is not significant during adiabatic mixing (Figure 2). Steady decomposition of thermally labile compounds in neutral solution, such as organic peroxides, requires a temperature higher than $\sim 80^{\circ} \mathrm{C}$ (Hart et al., 1949). Considering that the residence time of the PILS condensation chamber is only $1 \mathrm{~s}$, it is expected that the original structure of thermally labile organic molecules should be mostly intact in such a short timescale.

\section{Method application: IEPOX uptake onto acidified and hydrated ammonium sulfate particles}

The heterogeneous chemistry of isoprene epoxydiols (IEPOX), a second-generation product formed from isoprene photochemistry in the absence of NO, contributes significantly to the SOA formation (Paulot et al., 2009; Surratt et al., 2010; Lin et al., 
2012; Lin et al., 2014; Nguyen et al., 2014). Proposed mechanisms leading to SOA production involve the ring opening of the epoxide group, followed by the addition of available nucleophiles in the condensed phase, e.g., tetrol production via the addition of water and organosulfate production via the addition of sulfate (Eddingsaas et al., 2010; Surratt et al., 2010; Nguyen et al., 2014). The PILS + UPLC/ESI-Q-TOFMS method was employed to characterize the SOA formation and evolution via the reactive uptake of IEPOX onto hydrated and acidified ammonium sulfate particles. The IEPOX-derived SOA is a well-established system to test the performance of the PILS + UPLC/ESI-QTOFMS technique.

\subsection{Chamber experiment and instrument operation protocols}

The experiment was conducted in the Caltech $24 \mathrm{~m}^{3}$ Environmental Chamber maintained at $20{ }^{\circ} \mathrm{C}$. Detailed experimental protocols are presented in an earlier study (Nguyen et al., 2014). The general experimental procedure is as follows: 1) flushing the chamber with purified dry air for $24 \mathrm{~h}$ prior to the experiment; 2) humidifying the chamber to $\sim 78 \%$ RH by passing purified air through a Nafion membrane humidifier (FC200, Permapure LLC) that is kept wet by recirculation of $27^{\circ} \mathrm{C}$ ultra-pure water $(18$ $\mathrm{M} \Omega$, Millipore Milli-Q); 3) Injecting inorganic seed aerosols by atomizing an acidified ammonium sulfate aqueous solution $\left(0.06 \mathrm{M}\left(\mathrm{NH}_{4}\right)_{2} \mathrm{SO}_{4}+0.06 \mathrm{M} \mathrm{H}_{2} \mathrm{SO}_{4}\right)$ followed by a custom-built wet-wall denuder; and 4 ) injecting the gas-phase trans $\delta$-IEPOX isomer by evaporating several droplets in a glass bulb with $6 \mathrm{~L} \mathrm{~min}^{-1}$ of purified and heated dry air $\left(60{ }^{\circ} \mathrm{C}\right)$ for $\sim 100 \mathrm{~min}$.

The gas-phase IEPOX mixing ratio was monitored using a custom-modified Varian 1200 triple-quadrupole chemical ionization mass spectrometer (CIMS). In negative mode operation, $\mathrm{CF}_{3} \mathrm{O}^{-}$was used as the reagent ion to cluster with the analyte $[\mathrm{R}]$, producing $\left[\mathrm{R} \cdot \mathrm{CF}_{3} \mathrm{O}\right]^{-}$or $m / z[\mathrm{M}+85]^{-}$, where $\mathrm{M}$ is the molecular weight of the analyte. More details on the CIMS operation and data analysis are given by Zhang et al. (2015). Real-time particle mass spectra were collected continuously by an Aerodyne High Resolution Timeof-Flight Aerosol Mass Spectrometer (HR-AMS). The AMS switched once every minute between the high resolution "W-mode' and the lower resolution, higher sensitivity "V- 
mode". The V-mode was utilized for quantification, as the higher $\mathrm{m} / \mathrm{z}$ values exhibit a more favorable signal-to-noise ratio. The $\mathrm{W}$-mode was used for ion identification and clarification. More details on AMS operation and data analysis are given by Nguyen et al. (2014).

\subsection{Results and Discussions}

Shown in Fig. 6 (upper panel) are the CIMS signals at $m / z$ (-) 203, which represents the fluoride cluster product of IEPOX $\left(\mathrm{C}_{5} \mathrm{H}_{10} \mathrm{O}_{3} \cdot \mathrm{CF}_{3} \mathrm{O}^{-}\right)$, and organic particulate mass concentrations measured by the HR-AMS. Dominant ions observed in the HR-AMS spectra include $m / z 29, m / z 43, m / z 53$ (mostly $\mathrm{C}_{4} \mathrm{H}_{5}^{+}$) and $\mathrm{m} / z 82$ (mostly $\mathrm{C}_{5} \mathrm{H}_{6} \mathrm{O}^{+}$). The latter two are considered as the tracers for IEPOX derived organic aerosols (Lin et al., 2012; Budisulistiorini et al. 2013). The time-dependent trend of gas-phase IEPOX measured by CIMS during the injection period $(0-100 \mathrm{~min})$ is almost identical to the AMS measured total particulate organics, indicating the uptake of IEPOX and the subsequent reactions are essentially instantaneous. Gas-particle equilibrium is rapidly established after the IEPOX injection. Over the remaining $100 \mathrm{~min}$ of the experiment, AMS measured total organic mass is at a steady state, whereas the CIMS signal at $\mathrm{m} / \mathrm{z}(-)$ 203 exhibits a slow decay, which is likely a result of vapor wall losses of epoxide at high $\mathrm{RH}$ in the chamber.

For the PILS collected samples, the dominant ion observed in the UPLC/ESI-QTOFMS mass spectra in the negative mode is $\mathrm{C}_{5} \mathrm{H}_{11} \mathrm{SO}_{7}^{-}$, which corresponds to the IEPOX-derived hydroxyl sulfate ester. The hydroxyl sulfate ester dimer $\left(\mathrm{C}_{10} \mathrm{H}_{22} \mathrm{SO}_{10}^{-}\right)$is also observed in the form of $[\mathrm{M}-\mathrm{H}]^{-}$. Corresponding normalized mass spectra and temporal profiles of these two products are shown in Fig. 7 and the lower panel of Fig. 6, respectively. Prompt formation of sulfate ester was observed at the onset of IEPOX injection, and the time-dependent trend agrees with the AMS measured organic aerosol growth curve. The sulfate ester dimer, on the other hand, exhibits a 20 min induction period and creeps up over the course of the experiment. As authentic standards for IEPOX-derived organosulfates are not commercially available, the UPLC/ESI-Q-TOFMS was externally calibrated with a surrogate quantification standard, D-galactone 6-sulfate 
sodium salt (Sigma Aldrich $>98 \%$ ), the elemental composition and functionality of which most closely resemble that of the IEPOX-derived organosulfates. An ESI/MS response factor of $1.56 \times 10^{-5} \mathrm{ppm} / \mathrm{area}$, is obtained for the D-galactone 6-sulfate anion $\left(\mathrm{C}_{6} \mathrm{H}_{11} \mathrm{SO}_{9}^{-}\right)$at $m / z 259$ and applied to quantify the IEPOX-derived organosulfate ester and dimer. This sensitivity gives the overall equilibrium particle-phase organosulfate concentration of $\sim 12 \mu \mathrm{g} \mathrm{m}^{-3}$, which accounts for $17 \%$ of the AMS measured total organic masses. Note that although both belong to the organosulfate family and readily fragment to bisulfate anion $\left(\mathrm{HSO}_{4}^{-}\right)$in the $\mathrm{MS} / \mathrm{MS}$ analysis, the molecular properties of $\mathrm{D}$ galactone 6-sulfate $\left(\mathrm{C}_{6} \mathrm{H}_{11} \mathrm{SO}_{9}^{-}\right)$and IEPOX-derived sulfate $\left(\mathrm{C}_{5} \mathrm{H}_{11} \mathrm{SO}_{7}^{-}\right)$that affect the ESI ionization efficiency, such as $\mathrm{pK}_{\mathrm{a}}$ value, hydrophobicity, surface activity, etc., are not exactly the same. One should expect that the ESI-MS responses for these two organosulfates differ even under identical instrument operation conditions, and as a result, the conclusion that IEPOX-derived organosulfates account for $17 \%$ of the AMS measured total organic masses has a degree of uncertainty.

\section{Conclusions}

We introduce here the combination of two well-established analytical techniques, PILS and UPLC/ESI-Q-TOFMS, for time-resolved and quantitative measurement of chambergenerated organic aerosol chemical composition. The PILS+UPLC/ESI-Q-TOFMS system shows its promising utility, including relatively high-time resolution that allows for the investigation of aerosol dynamics and soft ionization to identify the integral molecular structure of particle-phase components. Additionally, the incorporation of liquid chromatography allows the pre-separation of species prior to the electrospray ionization, thus making the quantification of individual compounds plausible.

The PILS collection efficiency ( $\left.C E_{\mathrm{PILS}}\right)$ towards a population of sub-micron particles composed of pure chemical standards, including carboxylic acids, polyols, and amines, is estimated by simultaneously comparing the DMA vs. UPLC/ESI-Q-TOFMS measured total organic mass concentrations. The overall mass collection efficiency exceeds 0.6 for

particles with water solubility of $>1 \mathrm{~g} \mathrm{~L}^{-1}$, which corresponds to an average O:C ratio of $>0.26$. The AMS measured O:C ratios for SOA produced from photooxidation of a 
variety of VOCs (e.g., isoprene, toluene, $m$-xylene, $\alpha$-pinene, and naphthalene) in chamber experiments exceed 0.3 , for which it is possible to characterize time-resolved chemical composition of these SOA systems at the molecular level. Instrument sensitivity and linearity were tested using single component organic aerosols generated from sorbitol, azelaic acid, pinonic acid, and adipic acid.

The PILS+UPLC/ESI-Q-TOFMS method is then applied to study the SOA formation driven by reactive IEPOX uptake onto hydrated and acidic ammonium sulfate particles. For the first time, time-resolved traces of IEPOX-derived organosulfate ester and dimer are observed. The temporal profile of the organosulfate ester is essentially identical to the AMS observed organic growth curve. The equilibrium organosulfate concentration potentially accounts for a significant fraction of the overall organic aerosol mass resulting from reactive IEPOX uptake. The combination of PILS collection with UPLC/ESI-QTOFMS analysis offers a new approach for time-resolved and quantitative characterization of aerosol constituents at molecular level.

\section{Acknowledgement:}

This study was supported by Office of Naval Research grant N00014 - 14 - 1 - 0097 .

\section{References:}

Aiken, A.C., DeCarlo, P.F., Jimenez, J.L., 2007. Elemental analysis of organic species with electron ionization high-resolution mass spectrometry. Anal. Chem. 79, 8350-8358. Aiken, A.C., DeCarlo, P.F., Kroll, J.H., Worsnop, D.R., Huffman, J.A., Docherty, K.S., Ulbrich, I.M., Mohr, C., Kimmel, J.R., Sueper, D., Sun, Y., Zhang, Q., Trimborn, A., Northway, M., Ziemann, P.J., Canagaratna, M.R., Onasch, T.B., Alfarra, M.R., Prevot, A.S.H., Dommen, J., Duplissy, J., Metzger, A., Baltensperger, U., Jimenez, J.L., 2008. $\mathrm{O} / \mathrm{C}$ and $\mathrm{OM} / \mathrm{OC}$ ratios of primary, secondary, and ambient organic aerosols with highresolution time-of-flight aerosol mass spectrometry. Environ. Sci. Technol. 42, 44784485 . 
Aljawhary, D., Lee, A.K.Y., Abbatt, J.P.D., 2013. High-resolution chemical ionization mass spectrometry (ToF-CIMS): Application to study SOA composition and processing. Atmos. Meas. Tech. 6, 3211-3224.

Bateman, A.P., Nizkorodov, S.A., Laskin, J., Laskin, A., 2010. High-resolution electrospray ionization mass spectrometry analysis of water-soluble organic aerosols collected with a particle into liquid sampler. Anal. Chem. 82, 8010-8016.

Budisulistiorini, S.H., Canagaratna, M.R., Croteau, P.L., Marth, W.J., Baumann, K., Edgerton, E.S., Shaw, S.L., Knipping, E.M., Worsnop, D.R., Jayne, J.T., Gold, A., Surratt, J.D., 2013. Real-time continuous characterization of secondary organic aerosol derived from isoprene epoxydiols in downtown Atlanta, Georgia, using the Aerodyne Aerosol Chemical Speciation Monitor. Environ. Sci. Technol. 47, 5686-5694.

Canagaratna, M.R., Jayne, J.T., Jimenez, J.L., Allan, J.D., Alfarra, M.R., Zhang, Q., Onasch, T.B., Drewnick, F., Coe, H., Middlebrook, A., Delia, A., Williams, L.R., Trimborn, A.M., Northway, M.J., DeCarlo, P.F., Kolb, C.E., Davidovits, P., Worsnop, D.R., 2007. Chemical and microphysical characterization of ambient aerosols with the aerodyne aerosol mass spectrometer. Mass. Spectrom. Rev. 26, 185-222.

Chan, M.N., Surratt, J.D., Chan, A.W.H., Schilling, K., Offenberg, J.H., Lewandowski, M., Edney, E.O., Kleindienst, T.E., Jaoui, M., Edgerton, E.S., Tanner, R.L., Shaw, S.L., Zheng, M., Knipping, E.M., Seinfeld, J.H., 2011. Influence of aerosol acidity on the chemical composition of secondary organic aerosol from beta-caryophyllene. Atmos Chem. Phys. 11, 1735-1751.

Chhabra, P.S., Flagan, R.C., Seinfeld, J.H., 2010. Elemental analysis of chamber organic aerosol using an aerodyne high-resolution aerosol mass spectrometer. Atmos. Chem. Phys. 10, 4111-4131.

Chhabra, P.S., Ng, N.L., Canagaratna, M.R., Corrigan, A.L., Russell, L.M., Worsnop, D.R., Flagan, R.C., Seinfeld, J.H., 2011. Elemental composition and oxidation of chamber organic aerosol. Atmos. Chem. Phys. 11, 8827-8845.

Clark, C.H., Nakao, S., Asa-Awuku, A., Sato, K., Cocker, D.R., 2013. Real-time study of particle-phase products from alpha-pinene ozonolysis and isoprene photooxidation using 
Particle into Liquid Sampling directly coupled to a time-of-flight mass spectrometer (PILS-ToF). Aerosol Sci. Tech. 47, 1374-1382.

Dye, C., Yttri, K.E., 2005. Determination of monosaccharide anhydrides in atmospheric aerosols by use of high-performance liquid chromatography combined with highresolution mass spectrometry. Anal. Chem. 77, 1853-1858.

Dzepina, K., Arey, J., Marr, L.C., Worsnop, D.R., Salcedo, D., Zhang, Q., Onasch, T.B., Molina, L.T., Molina, M.J., Jimenez, J.L., 2007. Detection of particle-phase polycyclic aromatic hydrocarbons in Mexico City using an aerosol mass spectrometer. Int. J. Mass Spectrom. 263, 152-170.

Eddingsaas, N.C., VanderVelde, D.G., Wennberg, P.O., 2010. Kinetics and products of the acid-catalyzed ring-opening of atmospherically relevant butyl epoxy alcohols. J. Phys. Chem. A. 114, 8106-8113.

Ferge, T., Muhlberger, F., Zimmermann, R., 2005. Application of infrared laser desorption vacuum-UV single-photon ionization mass spectrometry for analysis of organic compounds from particulate matter filter samples. Anal. Chem. 77, 4528-4538.

Fahnestock, K.A.S., Yee, L.D., Loza, C.L., Coggon, M.M., Schwantes, R., Zhang, X., Dalleska, N.F., and Seinfeld, J.H. 2014. Secondary Organic Aerosol Composition from $\mathrm{C}_{12}$ Alkanes, J. Phys. Chem. A. 119 (19), 4281-4297.

Gao, S., Keywood, M., Ng, N.L., Surratt, J., Varutbangkul, V., Bahreini, R., Flagan, R.C., Seinfeld, J.H., 2004. Low-molecular-weight and oligomeric components in secondary organic aerosol from the ozonolysis of cycloalkenes and alpha-pinene. J. Phys. Chem. A. 108, 10147-10164.

Gelencser, A., Hoffer, A., Krivacsy, Z., Kiss, G., Molnar, A., Meszaros, E., 2002. On the possible origin of humic matter in fine continental aerosol. J. Geophys. Res.-Atmos. 107. doi: 10.1029/2001JD001299.

Graham, B., Mayol-Bracero, O.L., Guyon, P., Roberts, G.C., Decesari, S., Facchini, M.C., Artaxo, P., Maenhaut, W., Koll, P., Andreae, M.O., 2002. Water-soluble organic compounds in biomass burning aerosols over Amazonia - 1. Characterization by NMR and GC-MS. J. Geophys. Res.-Atmos. 107. doi: 10.1029/2001JD000336. 
Hart, A.B., 1949. Thermal decomposition of hydrogen peroxide in the vapour phase. Nature 163, 876-877.

Hearn, J.D., Smith, G.D., 2004. A chemical ionization mass spectrometry method for the online analysis of organic aerosols. Anal. Chem. 76, 2820-2826.

Hellen, H., Dommen, J., Metzger, A., Gascho, A., Duplissy, J., Tritscher, T., Prevot, A.S.H., Baltensperger, U., 2008. Using proton transfer reaction mass spectrometry for online analysis of secondary organic aerosols. Environ. Sci. Technol. 42, 7347-7353.

Hoffmann, T., Bandur, R., Marggraf, U., Linscheid, M., 1998. Molecular composition of organic aerosols formed in the alpha-pinene $/ \mathrm{O}_{3}$ reaction: Implications for new particle formation processes. J. Geophys. Res.-Atmos. 103, 25569-25578.

Iinuma, Y., Muller, C., Berndt, T., Boge, O., Claeys, M., Herrmann, H., 2007. Evidence for the existence of organosulfates from beta-pinene ozonolysis in ambient secondary organic aerosol. Environ. Sci. Technol. 41, 6678-6683.

Isaacman, G., Wilson, K.R., Chan, A.W.H., Worton, D.R., Kimmel, J.R., Nah, T., Hohaus, T., Gonin, M., Kroll, J.H., Worsnop, D.R., Goldstein, A.H., 2012. Improved resolution of hydrocarbon structures and constitutional isomers in complex mixtures using Gas Chromatography-Vacuum Ultraviolet-Mass Spectrometry. Anal. Chem. 84, 2335-2342.

Jang, M.S., Czoschke, N.M., Lee, S., Kamens, R.M., 2002. Heterogeneous atmospheric aerosol production by acid-catalyzed particle-phase reactions. Science. 298, 814-817.

Jimenez, J.L., Jayne, J.T., Shi, Q., Kolb, C.E., Worsnop, D.R., Yourshaw, I., Seinfeld, J.H., Flagan, R.C., Zhang, X.F., Smith, K.A., Morris, J.W., Davidovits, P., 2003. Ambient aerosol sampling using the Aerodyne Aerosol Mass Spectrometer. J. Geophys. Res.-Atmos. 108, 10.1029/2001JD001213.

Kalberer, M., Paulsen, D., Sax, M., Steinbacher, M., Dommen, J., Prevot, A.S.H., Fisseha, R., Weingartner, E., Frankevich, V., Zenobi, R., Baltensperger, U., 2004. Identification of polymers as major components of atmospheric organic aerosols. Science. 303, 1659-1662. 
Kuwata, M., Zorn, S.R., Martin, S.T., 2012. Using elemental ratios to predict the density of organic material composed of carbon, hydrogen, and oxygen. Environ. Sci. Technol. $46,787-794$.

LaFranchi, B.W., Petrucci, G.A., 2006. A comprehensive characterization of photoelectron resonance capture ionization aerosol mass spectrometry for the quantitative and qualitative analysis of organic particulate matter. Int. J. Mass Spectrom. 258, 120133.

Lavrich, R.J., Hays, M.D., 2007. Validation studies of thermal Extraction-GC/MS applied to source emissions aerosols. 1. Semivolatile analyte-nonvolatile matrix interactions. Anal. Chem. 79, 3635-3645.

Limbeck, A., Kulmala, M., Puxbaum, H., 2003. Secondary organic aerosol formation in the atmosphere via heterogeneous reaction of gaseous isoprene on acidic particles. Geophys. Res. Lett. 30, doi: 10.1029/2003GL017738.

Lin, Y.H., Zhang, Z.F., Docherty, K.S., Zhang, H.F., Budisulistiorini, S.H., Rubitschun, C.L., Shaw, S.L., Knipping, E.M., Edgerton, E.S., Kleindienst, T.E., Gold, A., Surratt, J.D., 2012. Isoprene epoxydiols as precursors to secondary organic aerosol formation: Acid-catalyzed reactive uptake studies with authentic compounds. Environ. Sci. Technol. $46,250-258$.

Lin, Y.H., Budisulistiorini, H., Chu, K., Siejack, R.A., Zhang, H.F., Riva, M., Zhang, Z.F., Gold, A., Kautzman, K.E., Surratt, J.D., 2014. Light-absorbing oligomer formation in secondary organic aerosol from reactive uptake of isoprene epoxydiols. Environ. Sci. Technol. 48, 12012-12021.

Lopez-Hilfiker, F.D., Mohr, C., Ehn, M., Rubach, F., Kleist, E., Wildt, J., Mentel, T.F., Lutz, A., Hallquist, M., Worsnop, D., Thornton, J.A., 2014. A novel method for online analysis of gas and particle composition: description and evaluation of a Filter Inlet for Gases and AEROsols (FIGAERO). Atmos. Meas. Tech. 7, 983-1001.

Loza, C.L., Craven, J.S., Yee, L.D., Coggon, M.M., Schwantes, R.H., Shiraiwa, M., Zhang, X., Schilling, K.A., Ng, N.L., Canagaratna, M.R., Ziemann, P.J., Flagan, R.C., 
Seinfeld, J.H., 2014. Secondary organic aerosol yields of 12-carbon alkanes. Atmos. Chem. Phys. 14, 1423-1439.

Ma, Y., Weber, R.J., Maxwell-Meier, K., Orsini, D.A., Lee, Y.N., Huebert, B.J., Howell, S.G., Bertram, T., Talbot, R.W., Dibb, J.E., Scheuer, E., 2004. Intercomparisons of airborne measurements of aerosol ionic chemical composition during TRACE-P and ACE-Asia. J. Geophys. Res.-Atmos. 109, doi: 10.1029/2003JD003673.

Nguyen, T.B., Coggon, M.M., Bates, K.H., Zhang, X., Schwantes, R.H., Schilling, K.A., Loza, C.L., Flagan, R.C., Wennberg, P.O., Seinfeld, J.H., 2014. Organic aerosol formation from the reactive uptake of isoprene epoxydiols (IEPOX) onto non-acidified inorganic seeds. Atmos. Chem. Phys. 14, 3497-3510.

Northway, M.J., Jayne, J.T., Toohey, D.W., Canagaratna, M.R., Trimborn, A., Akiyama, K.I., Shimono, A., Jimenez, J.L., DeCarlo, P.F., Wilson, K.R., Worsnop, D.R., 2007. Demonstration of a VUV lamp photoionization source for improved organic speciation in an aerosol mass spectrometer. Aerosol Sci. Tech. 41, 828-839.

Oakes, M., Rastogi, N., Majestic, B.J., Shafer, M., Schauer, J.J., Edgerton, E.S., Weber, R.J., 2010. Characterization of soluble iron in urban aerosols using near-real time data. J. Geophys. Res. -Atmos. 115, doi: 10.1029/2009jd012532.

Oktem, B., Tolocka, M.P., Johnston, M.V., 2004. On-line analysis of organic components in fine and ultrafine particles by photoionization aerosol mass spectrometry. Anal. Chem. $76,253-261$.

Orsini, D.A., Ma, Y.L., Sullivan, A., Sierau, B., Baumann, K., Weber, R.J., 2003. Refinements to the Particle-Into-Liquid Sampler (PILS) for ground and airborne measurements of water soluble aerosol composition. Atmos. Environ. 37, 1243-1259.

Parshintsev, J., Kivilompolo, M., Ruiz-Jimenez, J., Hartonen, K., Kulmala, M., Riekkola, M.L., 2010. Particle-into-Liquid Sampler on-line coupled with solid-phase extractionliquid chromatography-mass spectrometry for the determination of organic acids in atmospheric aerosols. J. Chromatogr. A. 1217, 5427-5433. 
Paulot, F., Crounse, J.D., Kjaergaard, H.G., Kurten, A., St Clair, J.M., Seinfeld, J.H., Wennberg, P.O., 2009. Unexpected epoxide formation in the gas-phase photooxidation of isoprene. Science. $325,730-733$.

Peltier, R.E., Weber, R.J., Sullivan, A.P., 2007. Investigating a liquid-based method for online organic carbon detection in atmospheric particles. Aerosol. Sci. Tech. 41, 11171127.

Rastogi, N., Oakes, M.M., Schauer, J.J., Shafer, M.M., Majestic, B.J., Weber, R.J., 2009. New technique for online measurement of water-soluble Fe (II) in atmospheric aerosols. Environ. Sci. Technol. 43, 2425-2430.

Schauer, J.J., Mader, B.T., Deminter, J.T., Heidemann, G., Bae, M.S., Seinfeld, J.H., Flagan, R.C., Cary, R.A., Smith, D., Huebert, B.J., Bertram, T., Howell, S., Kline, J.T., Quinn, P., Bates, T., Turpin, B., Lim, H.J., Yu, J.Z., Yang, H., Keywood, M.D., 2003. ACE-Asia intercomparison of a thermal-optical method for the determination of particlephase organic and elemental carbon. Environ. Sci. Technol. 37, 993-1001.

Simpson, C.D., Paulsen, M., Dills, R.L., Liu, L.J.S., Kalman, D.A., 2005. Determination of methoxyphenols in ambient atmospheric particulate matter: Tracers for wood combustion. Environ. Sci. Technol. 39, 631-637.

Smith, J.N., Moore, K.F., Eisele, F.L., Voisin, D., Ghimire, A.K., Sakurai, H., McMurry, P.H., 2005. Chemical composition of atmospheric nanoparticles during nucleation events in Atlanta. J. Geophys. Res.-Atmos. 110, doi: 10.1029/2005JD005912.

Sorooshian, A., Brechtel, F.J., Ma, Y.L., Weber, R.J., Corless, A., Flagan, R.C., Seinfeld, J.H., 2006. Modeling and characterization of a Particle-Into-Liquid Sampler (PILS). Aerosol. Sci. Tech. 40, 396-409.

Sorooshian, A., Ng, N.L., Chan, A.W.H., Feingold, G., Flagan, R.C., Seinfeld, J.H., 2007. Particulate organic acids and overall water-soluble aerosol composition measurements from the 2006 Gulf of Mexico Atmospheric Composition and Climate Study (GoMACCS). J. Geophys. Res.-Atmos. 112, doi: 10.1029/2007JD008537.

Sorooshian, A., Murphy, S.N., Hersey, S., Gates, H., Padro, L.T., Nenes, A., Brechtel, F.J., Jonsson, H., Flagan, R.C., Seinfeld, J.H., 2008. Comprehensive airborne 
characterization of aerosol from a major bovine source. Atmos. Chem. Phys. 8, 54895520.

Sullivan, R.C., Prather, K.A., 2005. Recent advances in our understanding of atmospheric chemistry and climate made possible by on-line aerosol analysis instrumentation. Anal. Chem. 77, 3861-3885.

Sullivan, A.P., Peltier, R.E., Brock, C.A., de Gouw, J.A., Holloway, J.S., Warneke, C., Wollny, A.G., Weber, R.J., 2006. Airborne measurements of carbonaceous aerosol soluble in water over northeastern United States: Method development and an investigation into water-soluble organic carbon sources. J. Geophys. Res.-Atmos. 111, doi: 10.1029/2006JD007072.

Surratt, J.D., Murphy, S.M., Kroll, J.H., Ng, N.L., Hildebrandt, L., Sorooshian, A., Szmigielski, R., Vermeylen, R., Maenhaut, W., Claeys, M., Flagan, R.C., Seinfeld, J.H., 2006. Chemical composition of secondary organic aerosol formed from the photooxidation of isoprene. J. Phys. Chem. A. 110, 9665-9690.

Surratt, J.D., Kroll, J.H., Kleindienst, T.E., Edney, E.O., Claeys, M., Sorooshian, A., Ng, N.L., Offenberg, J.H., Lewandowski, M., Jaoui, M., Flagan, R.C., Seinfeld, J.H., 2007a. Evidence for organosulfates in secondary organic aerosol. Environ. Sci. Technol. 41, $517-527$.

Surratt, J.D., Lewandowski, M., Offenberg, J.H., Jaoui, M., Kleindienst, T.E., Edney, E.O., Seinfeld, J.H., 2007b. Effect of acidity on secondary organic aerosol formation from isoprene. Environ. Sci. Technol. 41, 5363-5369.

Surratt, J.D., Gomez-Gonzalez, Y., Chan, A.W.H., Vermeylen, R., Shahgholi, M., Kleindienst, T.E., Edney, E.O., Offenberg, J.H., Lewandowski, M., Jaoui, M., Maenhaut, W., Claeys, M., Flagan, R.C., Seinfeld, J.H., 2008. Organosulfate formation in biogenic secondary organic aerosol. J. Phys. Chem. A. 112, 8345-8378.

Szmigielski, R., Surratt, J.D., Gomez-Gonzalez, Y., Van der Veken, P., Kourtchev, I., Vermeylen, R., Blockhuys, F., Jaoui, M., Kleindienst, T.E., Lewandowski, M., Offenberg, J.H., Edney, E.O., Seinfeld, J.H., Maenhaut, W., Claeys, M., 2007. 3-methyl- 
1,2,3-butanetricarboxylic acid: An atmospheric tracer for terpene secondary organic aerosol. Geophys. Res. Lett. 34, doi: 10.1029/2007GL031338.

Turpin, B.J., Saxena, P., Andrews, E., 2000. Measuring and simulating particulate organics in the atmosphere: problems and prospects. Atmos. Environ. 34, 2983-3013.

Weber, R.J., Orsini, D., Daun, Y., Lee, Y.N., Klotz, P.J., Brechtel, F., 2001. A particleinto-liquid collector for rapid measurement of aerosol bulk chemical composition. Aerosol. Sci. Tech. 35, 718-727.

Wolfs, I. and Desseyn, H.O. (1996). Characteristic vibrational pattern for the cyclic dimer carboxylic acid function in the solid state. Appl. Spectrosc. 50 (8), 1000-1006.

Yatavelli, R.L.N., Thornton, J.A., 2010. Particulate organic matter detection using a Micro-Orifice Volatilization Impactor coupled to a Chemical Ionization Mass Spectrometer (MOVI-CIMS). Aerosol. Sci. Tech. 44, 61-74.

Zahardis, J., LaFranchi, B.W., Petrucci, G.A., 2006. The heterogeneous reaction of particle-phase methyl esters and ozone elucidated by photoelectron resonance capture ionization: Direct products of ozonolysis and secondary reactions leading to the formation of ketones. Int. J. Mass Spectrom. 253, 38-47.

Zhang, X., Seinfeld, J.H., 2013. A functional group oxidation model (FGOM) for SOA formation and aging. Atmos. Chem. Phys. 13, 5907-5926.

Zhang, X., Cappa, C.D., Jathar, S.H., Mcvay, R.C., Ensberg, J.J., Kleeman, M.J., Seinfeld, J.H., 2014a. Influence of vapor wall loss in laboratory chambers on yields of secondary organic aerosol. P. Natl. Acad. Sci. USA. 111, 5802-5807.

Zhang, X., Schwantes, R.H., Coggon, M.M., Loza, C.L., Schilling, K.A., Flagan, R.C., Seinfeld, J.H., 2014b. Role of ozone in SOA formation from alkane photooxidation. Atmos. Chem. Phys. 14, 1733-1753.

Zhang, X., Schwantes, R.H., McVay, R.C., Lignell, H., Coggon, M.M., Flagan, R.C., Seinfeld, J.H., 2015. Vapor wall deposition in Teflon chambers. Atmos. Chem. Phys. 15, 4197-4214.

Zuend, A., Marcolli, C., Luo, B.P., Peter, T., 2008. A thermodynamic model of mixed 
organic-inorganic aerosols to predict activity coefficients. Atmos. Chem. Phys. 8, 45594593.

Zuend, A., Marcolli, C., Peter, T., Seinfeld, J.H., 2010. Computation of liquid-liquid equilibria and phase stabilities: implications for RH-dependent gas/particle partitioning of organic-inorganic aerosols. Atmos. Chem. Phys. 10, 7795-7820. 
Table 1. Compounds used for method development.

\begin{tabular}{|c|c|c|c|c|c|c|}
\hline Compound & $\begin{array}{l}\text { Molecular } \\
\text { Formula }\end{array}$ & Chemical Structure & Exact Mass & $\begin{array}{c}m / z \\
\text { (error } / \mathrm{mDa})\end{array}$ & $\begin{array}{c}\text { Water } \\
\text { Solubility } \\
\text { at } 20^{\circ} \mathrm{C}^{\text {a }}\end{array}$ & $\begin{array}{l}\text { Vapor Pressure } \\
(\text { atm at } 298 \mathrm{~K})^{\mathrm{b}}\end{array}$ \\
\hline adenine & $\mathrm{C}_{5} \mathrm{H}_{5} \mathrm{~N}_{5}$ & & 135.0545 & $\begin{array}{c}{[\mathrm{M}+\mathrm{H}]^{+}} \\
\quad(1.6)\end{array}$ & $0.103 \mathrm{~g} / \mathrm{L}$ & $8.117 \times 10^{-5}$ \\
\hline adonitol & $\mathrm{C}_{5} \mathrm{H}_{12} \mathrm{O}_{5}$ & & 152.0685 & $\begin{array}{c}{[\mathrm{M}-\mathrm{H}]^{-}} \\
(4.8)\end{array}$ & $50.0 \mathrm{~g} / \mathrm{L}$ & $7.711 \times 10^{-12}$ \\
\hline adipic acid & $\mathrm{C}_{6} \mathrm{H}_{10} \mathrm{O}_{4}$ & & 146.0579 & $\begin{array}{c}{[\mathrm{M}-\mathrm{H}]^{-}} \\
(0.6)\end{array}$ & $0.25 \mathrm{~g} / \mathrm{L}$ & $3.292 \times 10^{-9}$ \\
\hline d-sorbitol & $\mathrm{C}_{6} \mathrm{H}_{14} \mathrm{O}_{6}$ & & 180.0634 & $\begin{array}{c}{[\mathrm{M}-\mathrm{H}]^{-}} \\
(2.5)\end{array}$ & $182.0 \mathrm{~g} / \mathrm{L}$ & $2.424 \times 10^{-14}$ \\
\hline $\begin{array}{l}\text { diethylmalonic } \\
\text { acid }\end{array}$ & $\mathrm{C}_{7} \mathrm{H}_{12} \mathrm{O}_{4}$ & & 160.0736 & $\begin{array}{c}{\left[\mathrm{M}-\mathrm{CO}_{2}-\mathrm{H}\right]^{-}} \\
(0.1)\end{array}$ & $25.0 \mathrm{~g} / \mathrm{L}$ & $2.696 \times 10^{-9}$ \\
\hline vanillic acid & $\mathrm{C}_{8} \mathrm{H}_{8} \mathrm{O}_{4}$ & & 168.0423 & $\begin{array}{c}{[\mathrm{M}-\mathrm{H}]^{-}} \\
(-1.8)\end{array}$ & $1.5 \mathrm{~g} / \mathrm{L}$ & $7.940 \times 10^{-10}$ \\
\hline Azelaic acid & $\mathrm{C}_{9} \mathrm{H}_{16} \mathrm{O}_{4}$ & $\mathrm{HO}^{-1} \mathrm{Cl}$ & 188.1049 & $\begin{array}{r}{[\mathrm{M}-\mathrm{H}]^{-}} \\
(-4.2)\end{array}$ & $2.14 \mathrm{~g} / \mathrm{L}$ & $1.151 \times 10^{-10}$ \\
\hline$c i s$-pinonic acid & $\mathrm{C}_{10} \mathrm{H}_{16} \mathrm{O}_{3}$ & & 184.1099 & $\begin{array}{c}{[\mathrm{M}-\mathrm{H}]^{-}} \\
(1.9)\end{array}$ & $7.8 \mathrm{~g} / \mathrm{L}$ & $1.485 \times 10^{-7}$ \\
\hline myristic acid & $\mathrm{C}_{14} \mathrm{H}_{28} \mathrm{O}_{2}$ & $\mathrm{HO}^{-1}$ & 228.2089 & $\begin{array}{c}{[\mathrm{M}-\mathrm{H}]^{-}} \\
(0.7)\end{array}$ & $20.0 \mathrm{mg} / \mathrm{L}$ & $6.711 \times 10^{-9}$ \\
\hline palmitic acid & $\mathrm{C}_{16} \mathrm{H}_{32} \mathrm{O}_{2}$ & ${ }_{\mathrm{HO}} \stackrel{\mathrm{O}}{\mathrm{Cl}}_{\mathrm{Cl}}$ & 256.2402 & $\begin{array}{c}{[\mathrm{M}-\mathrm{H}]^{-}} \\
(1.3)\end{array}$ & $7.2 \mathrm{mg} / \mathrm{L}$ & $7.175 \times 10^{-10}$ \\
\hline
\end{tabular}

${ }^{a}$ Water solubility data source: Yaw C. L.: Handbook of Thermodynamic and Physical Properties of Chemical Compounds, Knovel, 2003.

b Vapor pressure is estimated by taking the average of predictions from 'EVAPORATION' (Compernolle et al., 2011) and 'SIMPOL.1' (Pankow and Asher, 2008) 

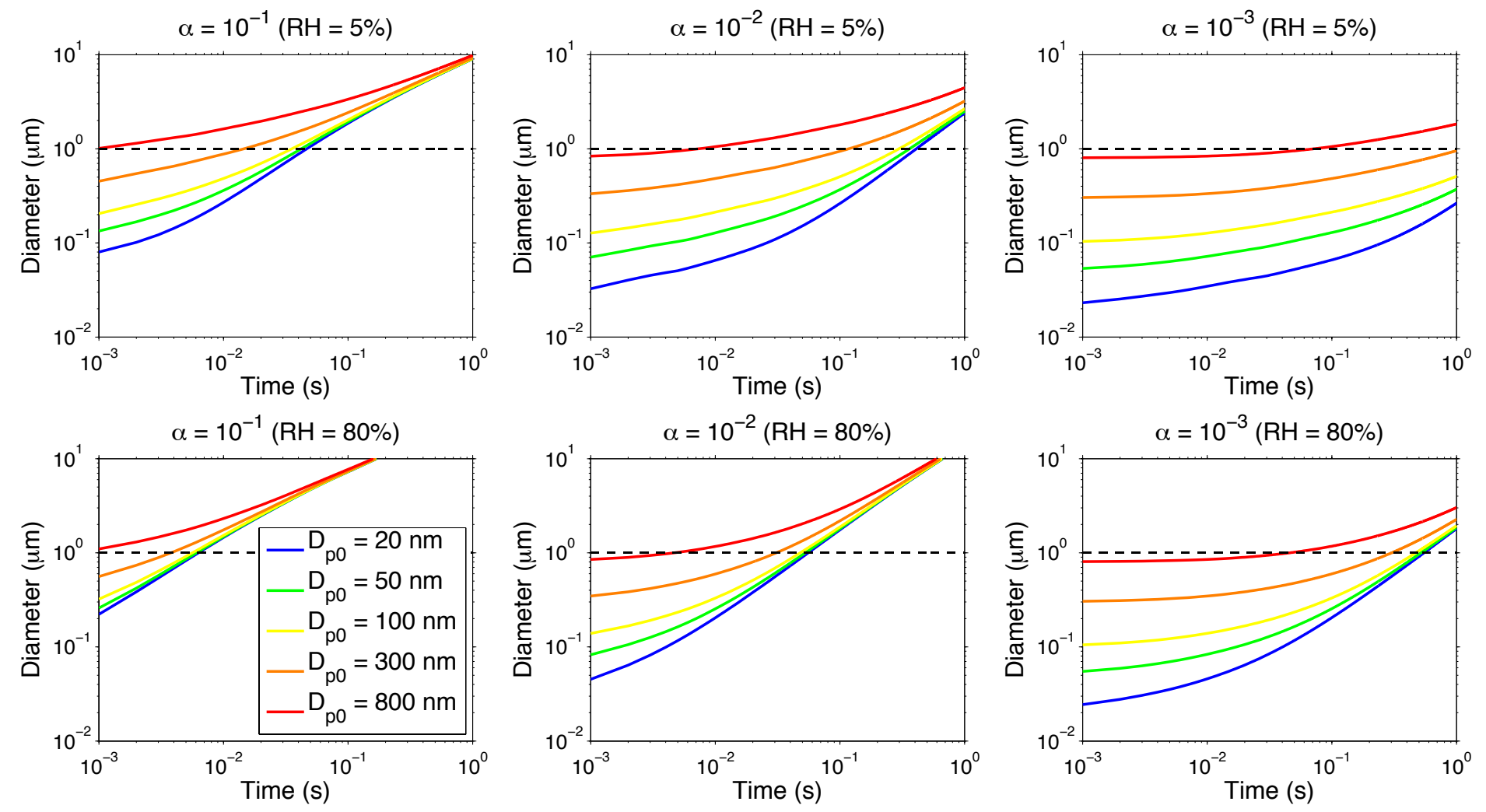

Figure 1. Simulations of particle condensational growth over an initial size range of $20 \mathrm{~nm}$ to $800 \mathrm{~nm}$ diameter in the presence of supersaturated water vapor for different assumed water accommodation coefficients $\left(\alpha_{\mathrm{w}}=10^{-3}, 10^{-2}\right.$, and $\left.10^{-1}\right)$ at initial relative humidities (RH) of $5 \%$ (upper panel) and 80\% (lower panel) in the chamber. The black dashed line denotes the threshold value (1 $1 \mu \mathrm{m}$ in diameter) of particle size for effective PILS collection. 


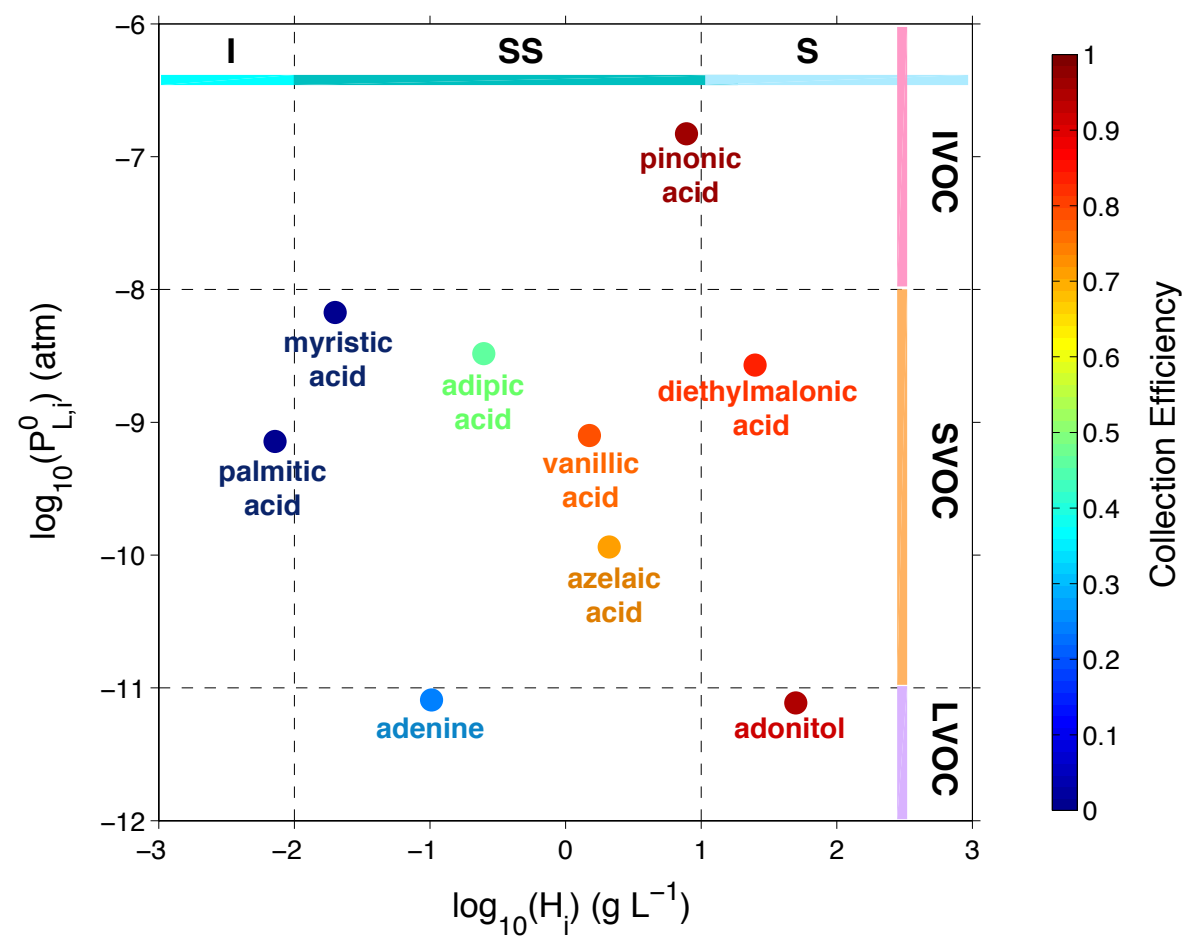

Figure 2. Measured PILS overall mass collection efficiency for the test organic aerosols as a function of volatility, which is defined as the vapor pressure of compound $i$ as pure liquid at $20{ }^{\circ} \mathrm{C}$ on the $\operatorname{logarithm}$ scale $\left(\log _{10} \mathrm{P}_{\mathrm{L}, \mathrm{i}}^{0}\right.$, atm), and water solubility, which is defined here as the maximum amount of the compound $i$ that will dissolve in pure water at $20{ }^{\circ} \mathrm{C}$ on the logarithm scale $\left(\log _{10} \mathrm{H}_{\mathrm{i}}, \mathrm{g} \mathrm{L}^{-1}\right)$. Compound volatility is categorized according to intermediate volatility organic compound (IVOC), semi-volatile organic compound (SVOC), and low volatility organic compound (LVOC). Water solubility is categorized broadly as insoluble (I), slightly soluble (SS), and soluble (S). 


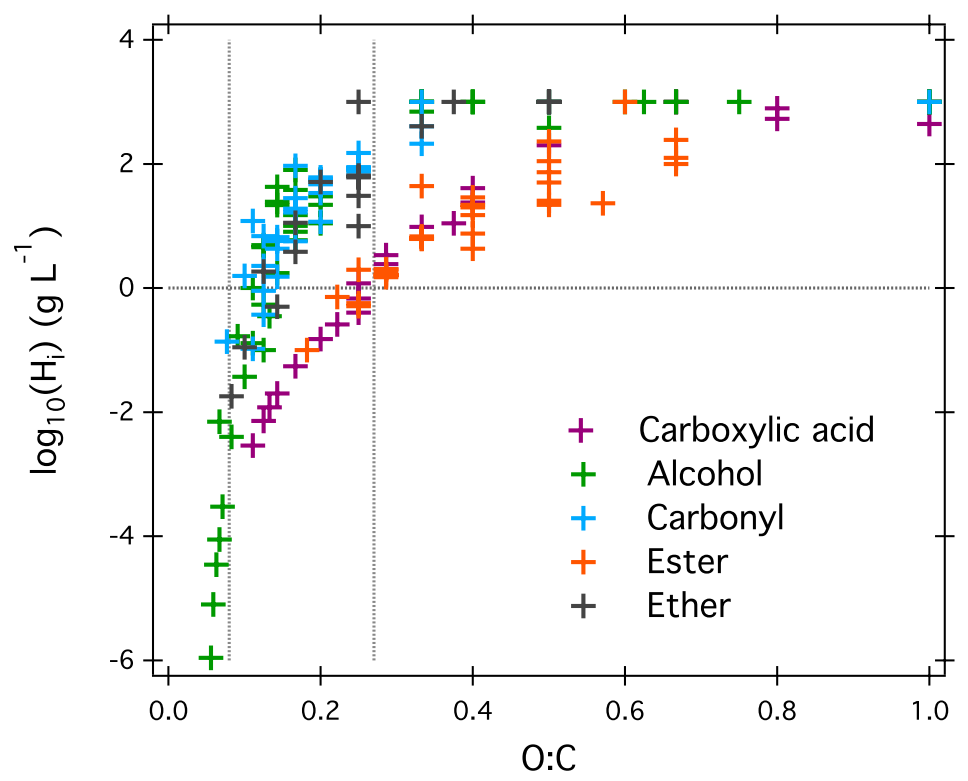

Figure 3. Water solubility of carboxylic acid, alcohol, carbonyl, ester, and ether standards at $20{ }^{\circ} \mathrm{C}$ as a function of their O:C ratios. Each data point represents an individual compound with certain functionalities. The horizontal gray line represents the water solubility threshold $\left(1 \mathrm{~g} \mathrm{~L}^{-1}\right)$ at which the PILS collection efficiency of $\sim 0.6$ will be achieved. The two vertical gray lines define a region of average particle $\mathrm{O}: \mathrm{C}$ ratios that correspond to the water solubility threshold. Data source: Yaw C. L.: Handbook of Thermodynamic and Physical Properties of Chemical Compounds, Knovel, 2003. 

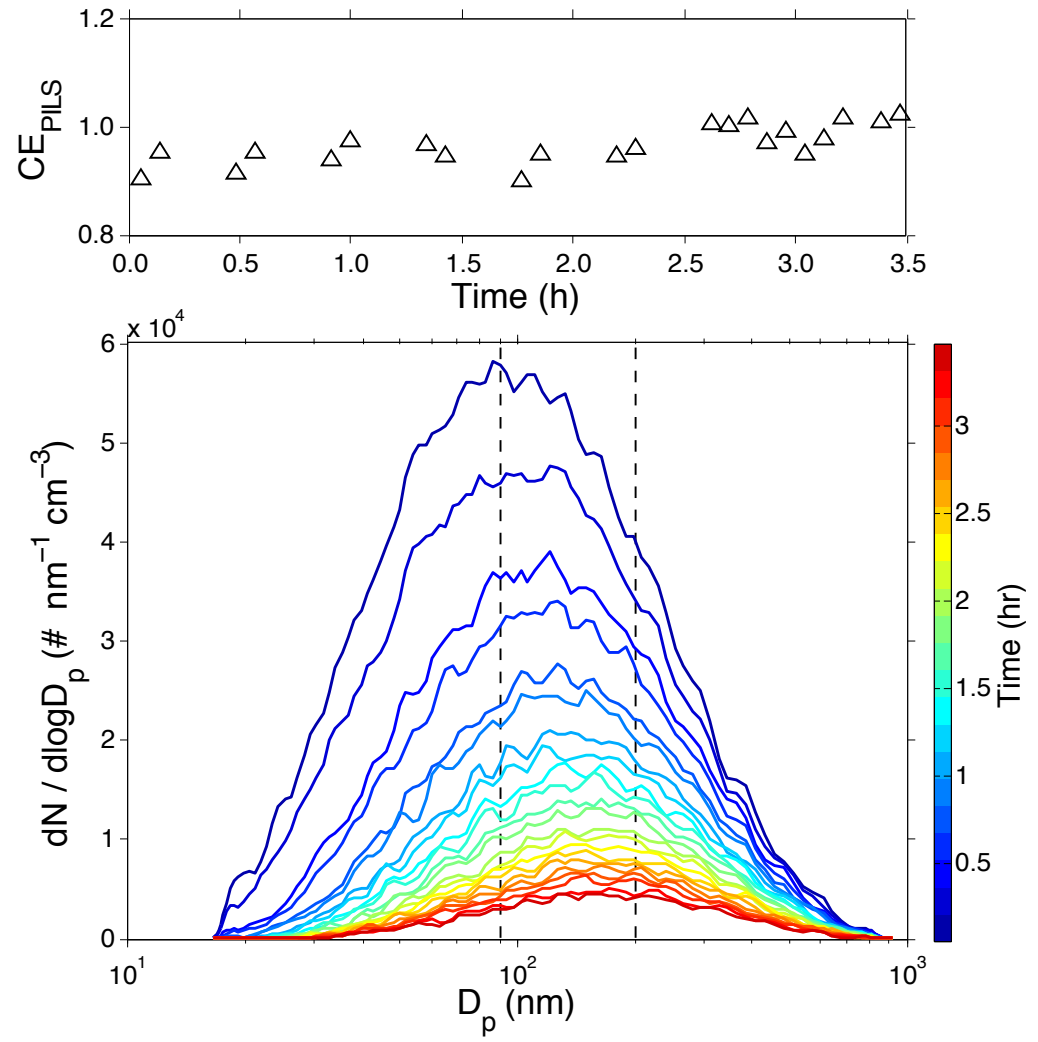

Figure 4. PILS overall mass collection efficiency (upper panel) for cis-pinonic acid aerosols as a function of particle number distribution (lower panel). Over $\sim 3 \mathrm{~h}$, aerosol wall deposition from intense turbulent mixing in the chamber caused the number median aerosol diameter to shift from $90 \mathrm{~nm}$ to $200 \mathrm{~nm}$. 

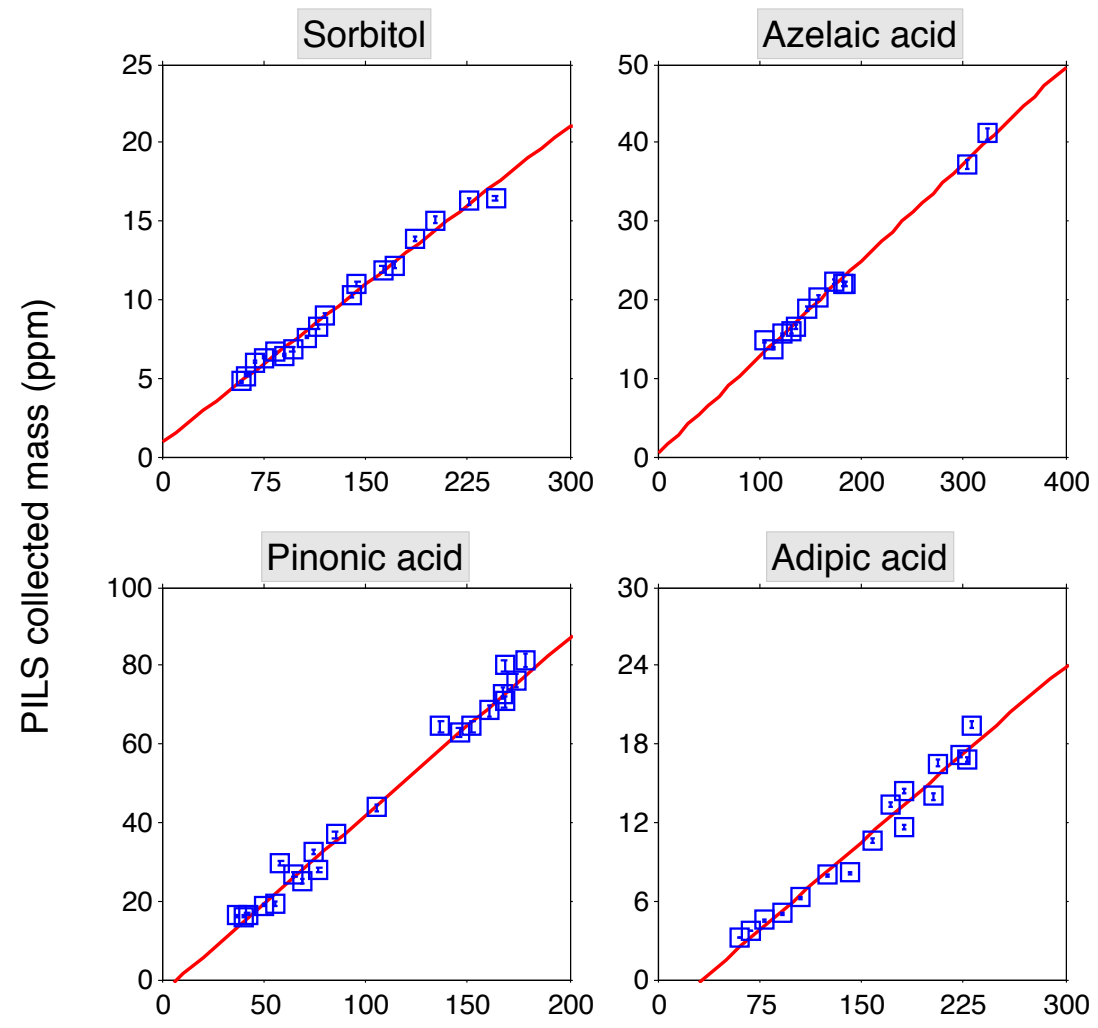

DMA measured mass $\left(\mu \mathrm{g} / \mathrm{m}^{3}\right)$

Figure 5. UPLC/ESI-Q-TOFMS measured mass concentration of sorbitol, azelaic acid, pinonic acid, and adipic acid in PILS samples versus the DMA-measured total particle mass. Linear fits to the data are shown with the mean $\mathrm{R}^{2}=0.99$. 

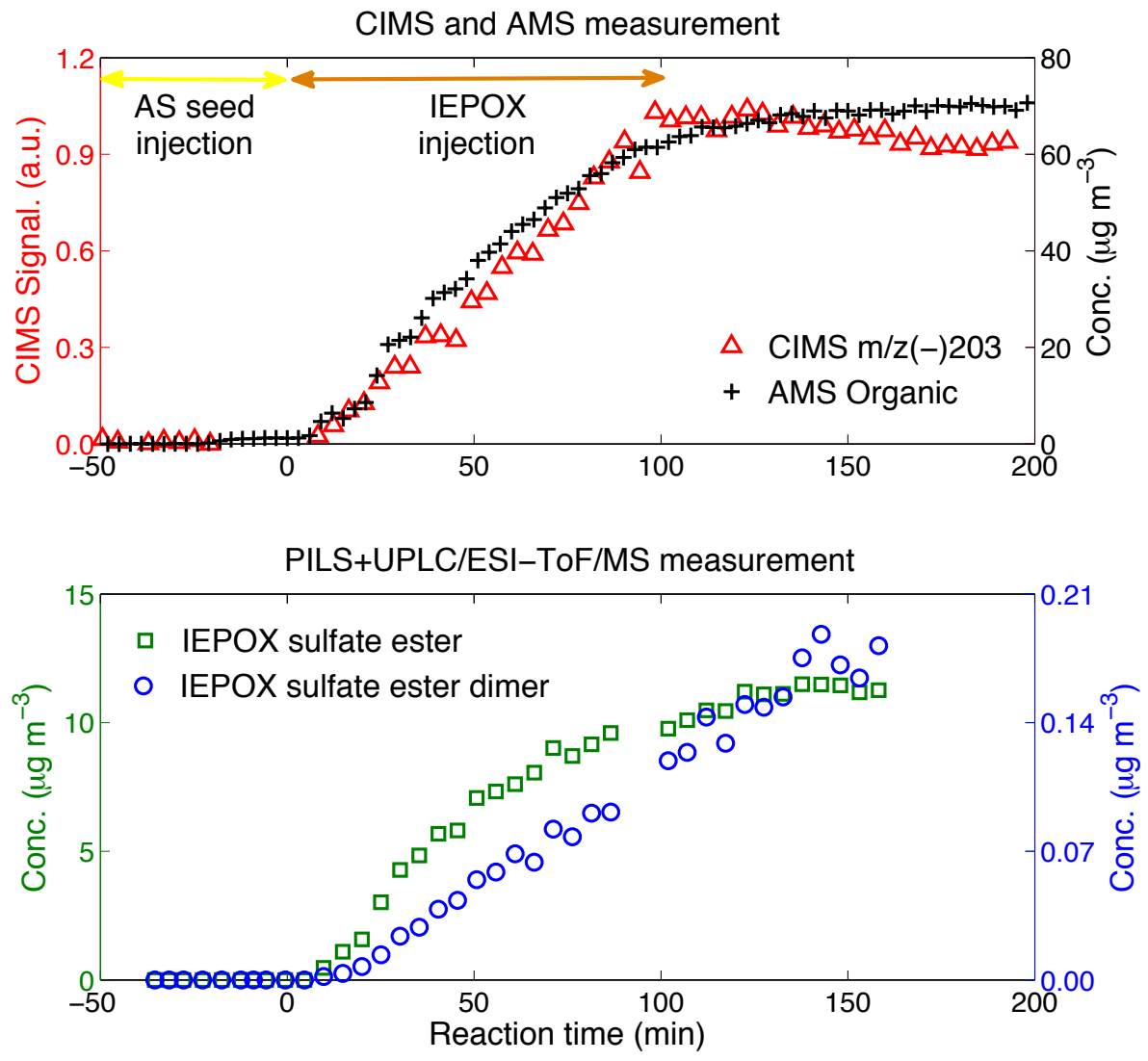

Figure 6. Temporal profiles of normalized CIMS signals at $\mathrm{m} / \mathrm{z}(-)$ 203, which represents the fluoride cluster product of IEPOX $\left(\mathrm{C}_{5} \mathrm{H}_{10} \mathrm{O}_{3} \cdot \mathrm{CF}_{3} \mathrm{O}^{-}\right)$, and AMS measured total organic (upper panel), as well as IEPOX-derived sulfate ester and dimer measured by the PILS+UPLC/ESI-Q-TOFMS technique (lower panel). 

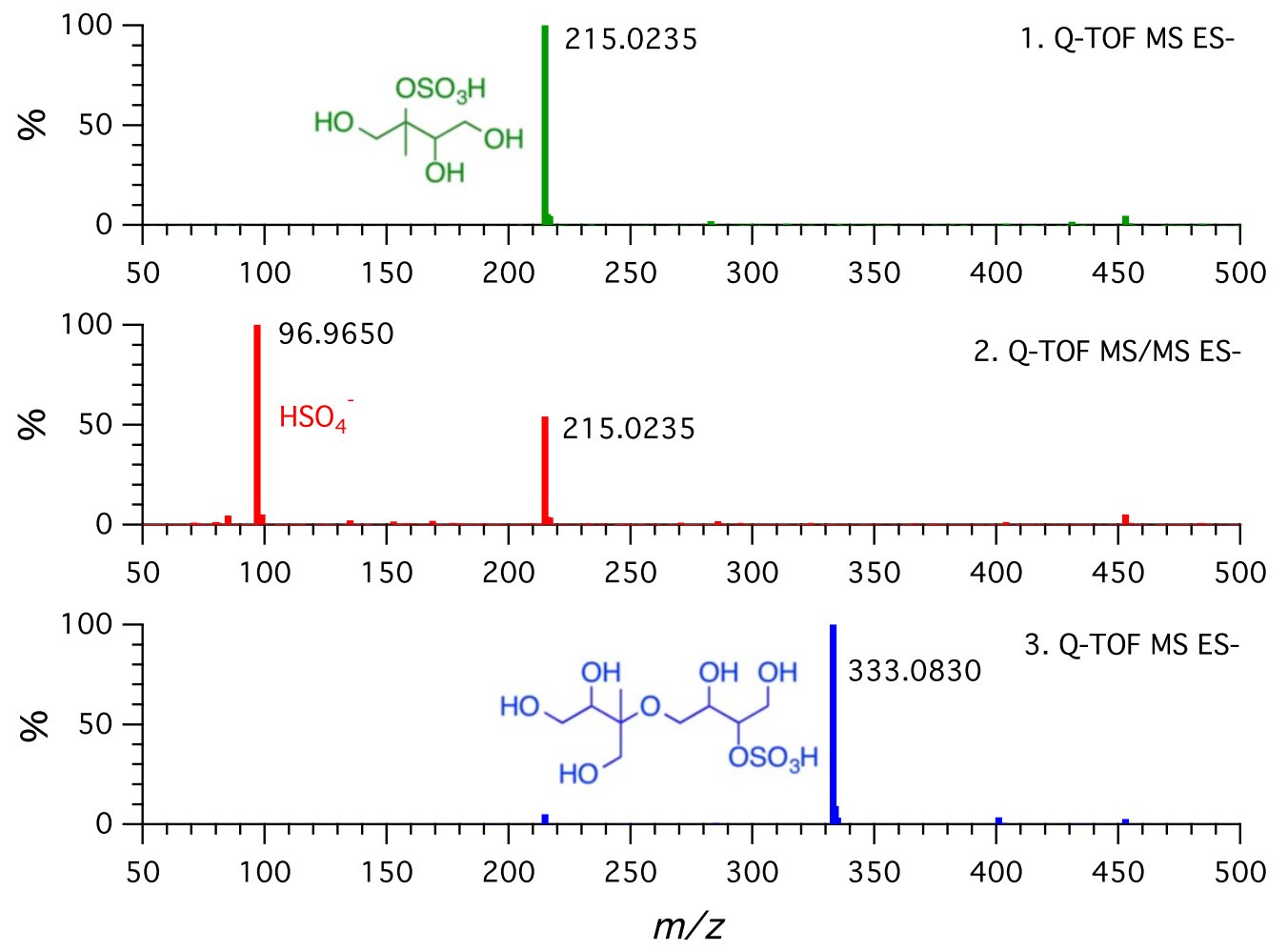

Figure 7. (Panel 1) Mass spectrum for the IEPOX-derived hydroxyl sulfate ester, detected as $m / z=215$ in the form of $\mathrm{C}_{5} \mathrm{H}_{11} \mathrm{SO}_{7}^{-}\left(\left[\mathrm{M}-\mathrm{H}^{-}\right]\right)$. (Panel 2) The MS/MS fragmentation confirms the organosulfate with the $\mathrm{m} / \mathrm{z} 97\left(\mathrm{HSO}_{4}^{-}\right)$daughter ion. (Panel 3) Mass spectrum for the IEPOX-derived hydroxyl sulfate ester dimer, detected as $m / z=333$ in the form of $\mathrm{C}_{10} \mathrm{H}_{20} \mathrm{SO}_{6}^{-}\left(\left[\mathrm{M}-\mathrm{H}^{-}\right]\right)$. 
Table 1. Compounds used for method development.

\begin{tabular}{|c|c|c|c|c|c|c|}
\hline Compound & $\begin{array}{l}\text { Molecular } \\
\text { Formula }\end{array}$ & Chemical Structure & Exact Mass & $\begin{array}{c}m / z \\
\text { (error / mDa) }\end{array}$ & $\begin{array}{c}\text { Water } \\
\text { Solubility } \\
\text { at } 20^{\circ} \mathrm{C}^{\text {a }}\end{array}$ & $\begin{array}{l}\text { Vapor Pressure } \\
(\text { atm at } 298 \mathrm{~K})\end{array}$ \\
\hline adenine & $\mathrm{C}_{5} \mathrm{H}_{5} \mathrm{~N}_{5}$ & & 135.0545 & $\begin{array}{c}{[\mathrm{M}+\mathrm{H}]^{+}} \\
(1.6)\end{array}$ & $0.103 \mathrm{~g} / \mathrm{L}$ & $8.117 \times 10^{-5}$ \\
\hline adonitol & $\mathrm{C}_{5} \mathrm{H}_{12} \mathrm{O}_{5}$ & & 152.0685 & $\begin{array}{c}{[\mathrm{M}-\mathrm{H}]^{-}} \\
(4.8)\end{array}$ & $50.0 \mathrm{~g} / \mathrm{L}$ & $7.711 \times 10^{-12}$ \\
\hline adipic acid & $\mathrm{C}_{6} \mathrm{H}_{10} \mathrm{O}_{4}$ & & 146.0579 & $\begin{array}{c}{[\mathrm{M}-\mathrm{H}]^{-}} \\
(0.6)\end{array}$ & $0.25 \mathrm{~g} / \mathrm{L}$ & $3.292 \times 10^{-9}$ \\
\hline d-sorbitol & $\mathrm{C}_{6} \mathrm{H}_{14} \mathrm{O}_{6}$ & & 180.0634 & $\begin{array}{c}{[\mathrm{M}-\mathrm{H}]^{-}} \\
(2.5)\end{array}$ & $182.0 \mathrm{~g} / \mathrm{L}$ & $2.424 \times 10^{-14}$ \\
\hline $\begin{array}{l}\text { diethylmalonic } \\
\text { acid }\end{array}$ & $\mathrm{C}_{7} \mathrm{H}_{12} \mathrm{O}_{4}$ & & 160.0736 & $\begin{array}{c}{\left[\mathrm{M}-\mathrm{CO}_{2}-\mathrm{H}\right]^{-}} \\
\quad(0.1)\end{array}$ & $25.0 \mathrm{~g} / \mathrm{L}$ & $2.696 \times 10^{-9}$ \\
\hline vanillic acid & $\mathrm{C}_{8} \mathrm{H}_{8} \mathrm{O}_{4}$ & & 168.0423 & $\begin{array}{c}{[\mathrm{M}-\mathrm{H}]^{-}} \\
(-1.8)\end{array}$ & $1.5 \mathrm{~g} / \mathrm{L}$ & $7.940 \times 10^{-10}$ \\
\hline Azelaic acid & $\mathrm{C}_{9} \mathrm{H}_{16} \mathrm{O}_{4}$ & & 188.1049 & $\begin{array}{c}{[\mathrm{M}-\mathrm{H}]^{-}} \\
(-4.2)\end{array}$ & $2.14 \mathrm{~g} / \mathrm{L}$ & $1.151 \times 10^{-10}$ \\
\hline cis-pinonic acid & $\mathrm{C}_{10} \mathrm{H}_{16} \mathrm{O}_{3}$ & 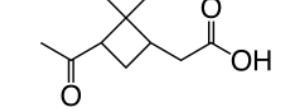 & 184.1099 & $\begin{array}{c}{[\mathrm{M}-\mathrm{H}]^{-}} \\
(1.9)\end{array}$ & $7.8 \mathrm{~g} / \mathrm{L}$ & $1.485 \times 10^{-7}$ \\
\hline myristic acid & $\mathrm{C}_{14} \mathrm{H}_{28} \mathrm{O}_{2}$ & $\mathrm{HO}^{-}$ & 228.2089 & $\begin{array}{c}{[\mathrm{M}-\mathrm{H}]^{-}} \\
(0.7)\end{array}$ & $20.0 \mathrm{mg} / \mathrm{L}$ & $6.711 \times 10^{-9}$ \\
\hline palmitic acid & $\mathrm{C}_{16} \mathrm{H}_{32} \mathrm{O}_{2}$ & $\mathrm{HO}^{-}$ & 256.2402 & $\begin{array}{c}{[\mathrm{M}-\mathrm{H}]^{-}} \\
(1.3)\end{array}$ & $7.2 \mathrm{mg} / \mathrm{L}$ & $7.175 \times 10^{-10}$ \\
\hline
\end{tabular}

a Water solubility data source: Yaw C. L.: Handbook of Thermodynamic and Physical Properties of Chemical Compounds, Knovel, 2003.

${ }^{b}$ Vapor pressure is estimated by taking the average of predictions from 'EVAPORATION' (Compernolle et al., 2011) and 'SIMPOL.1' (Pankow and Asher, 2008) 

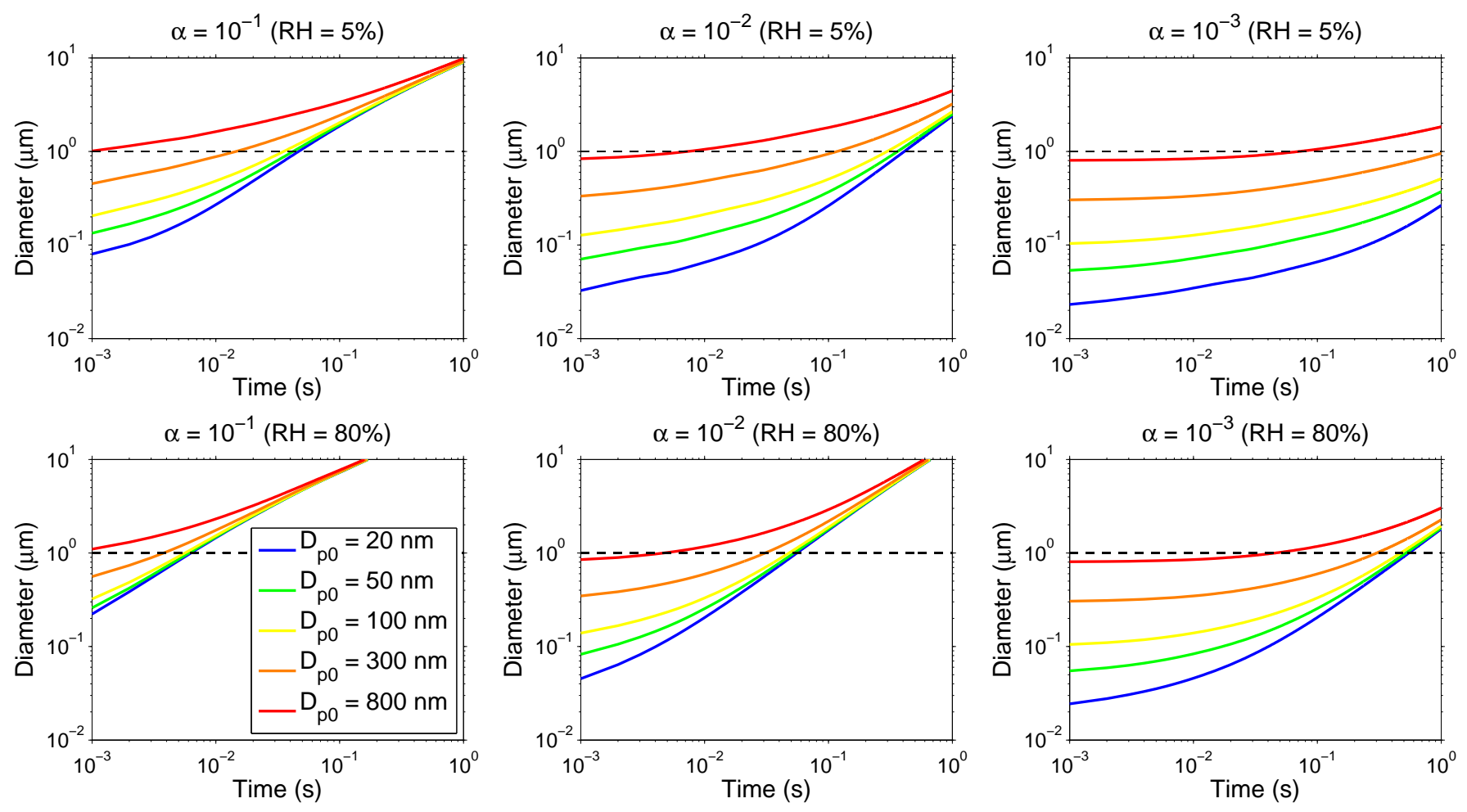


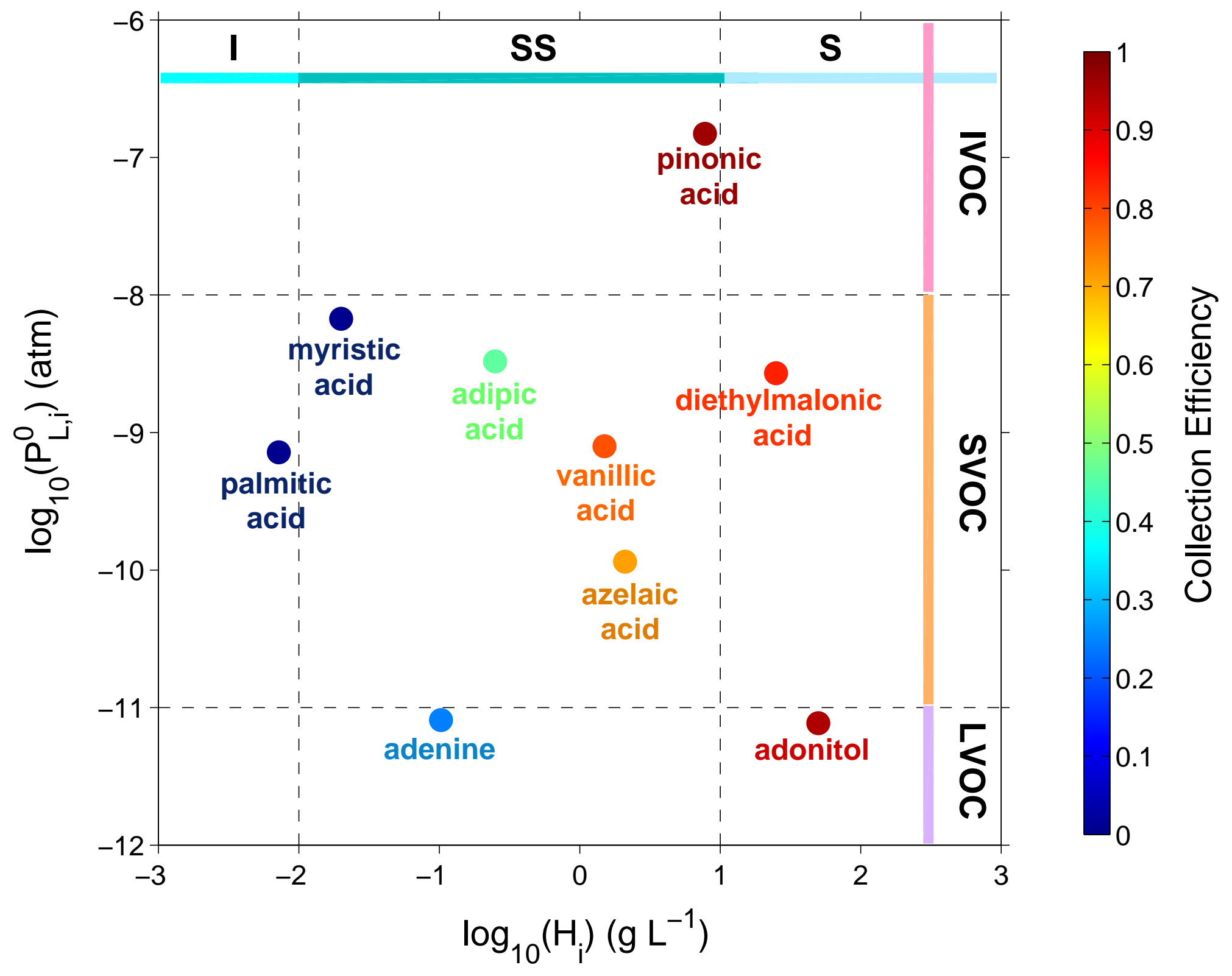




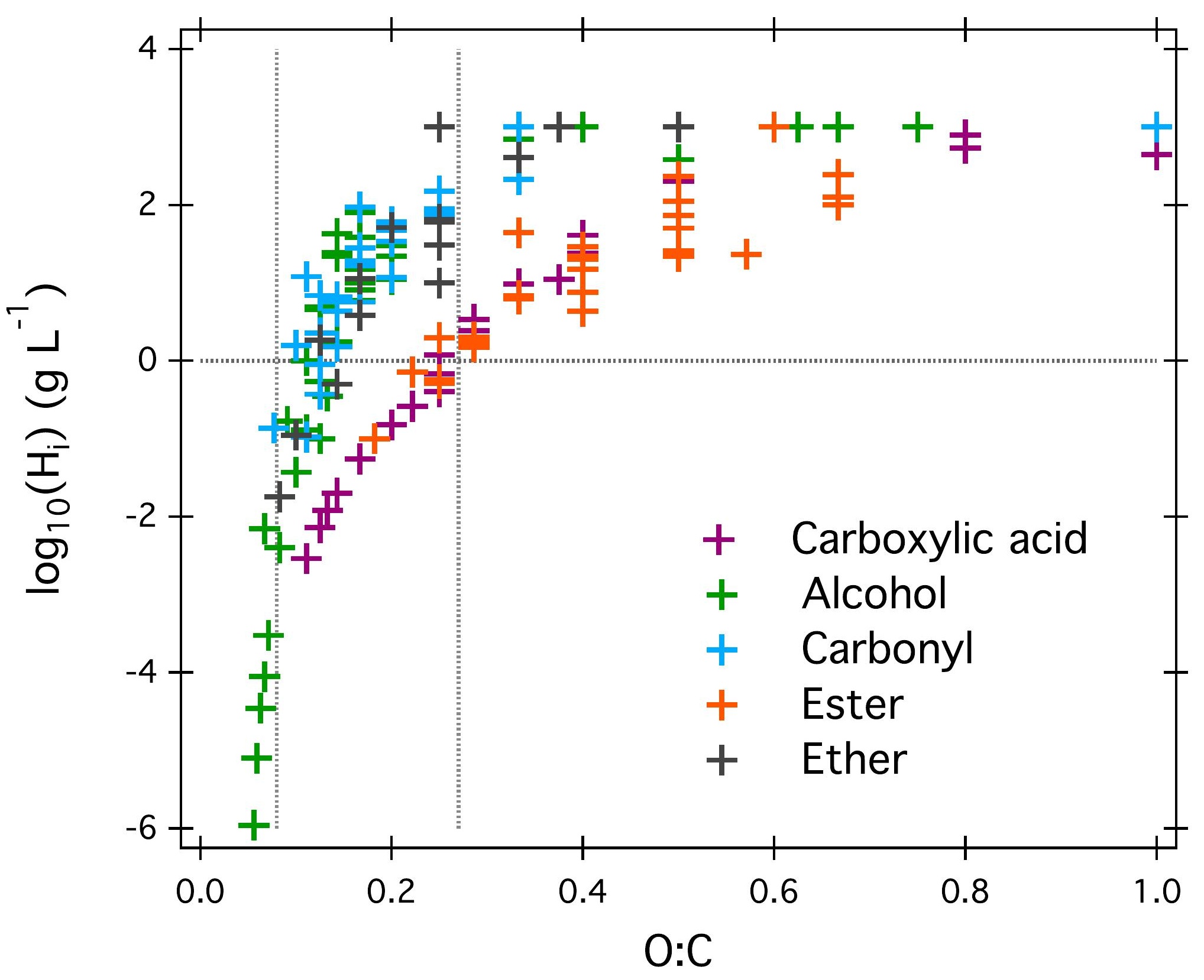



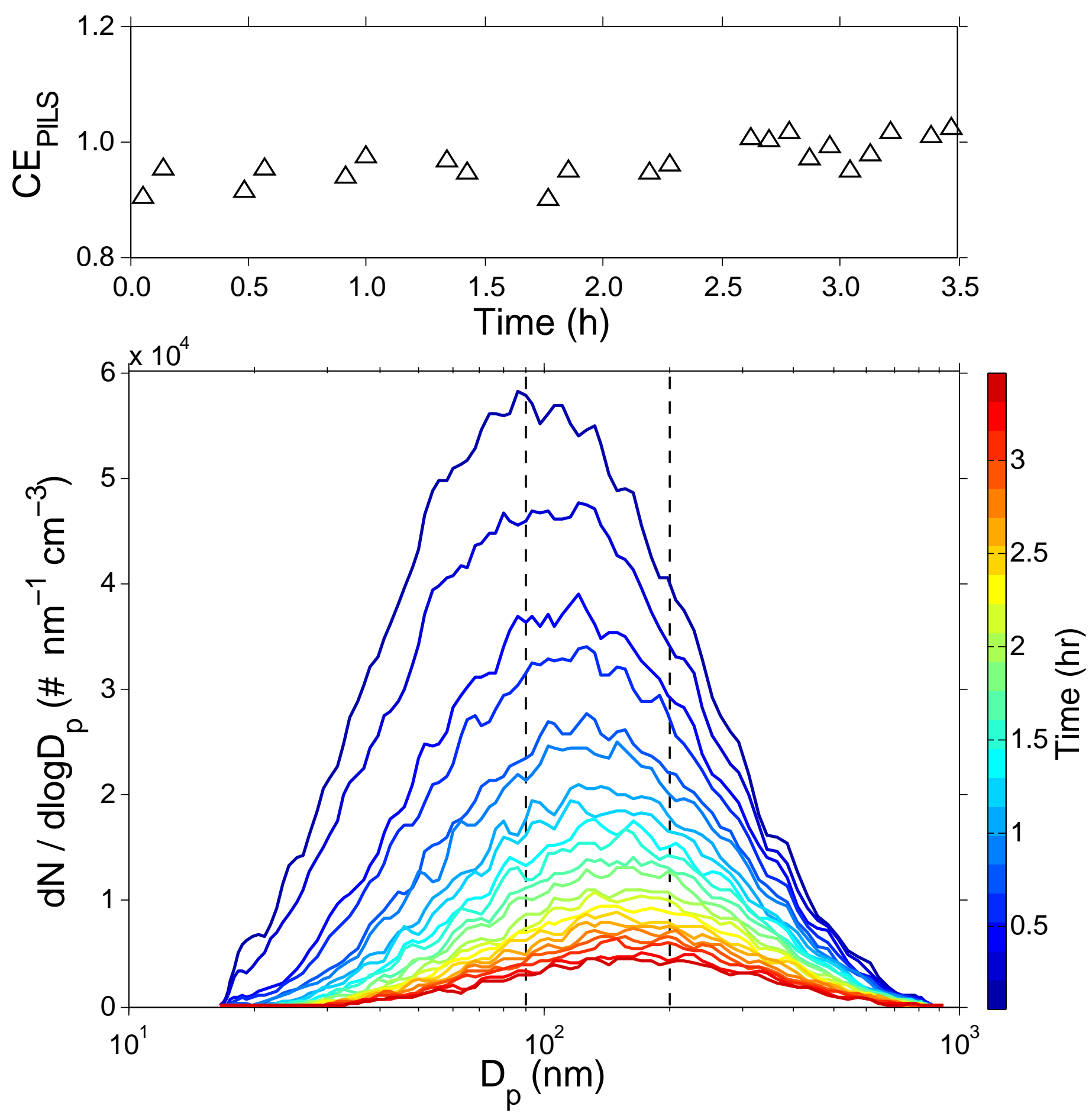

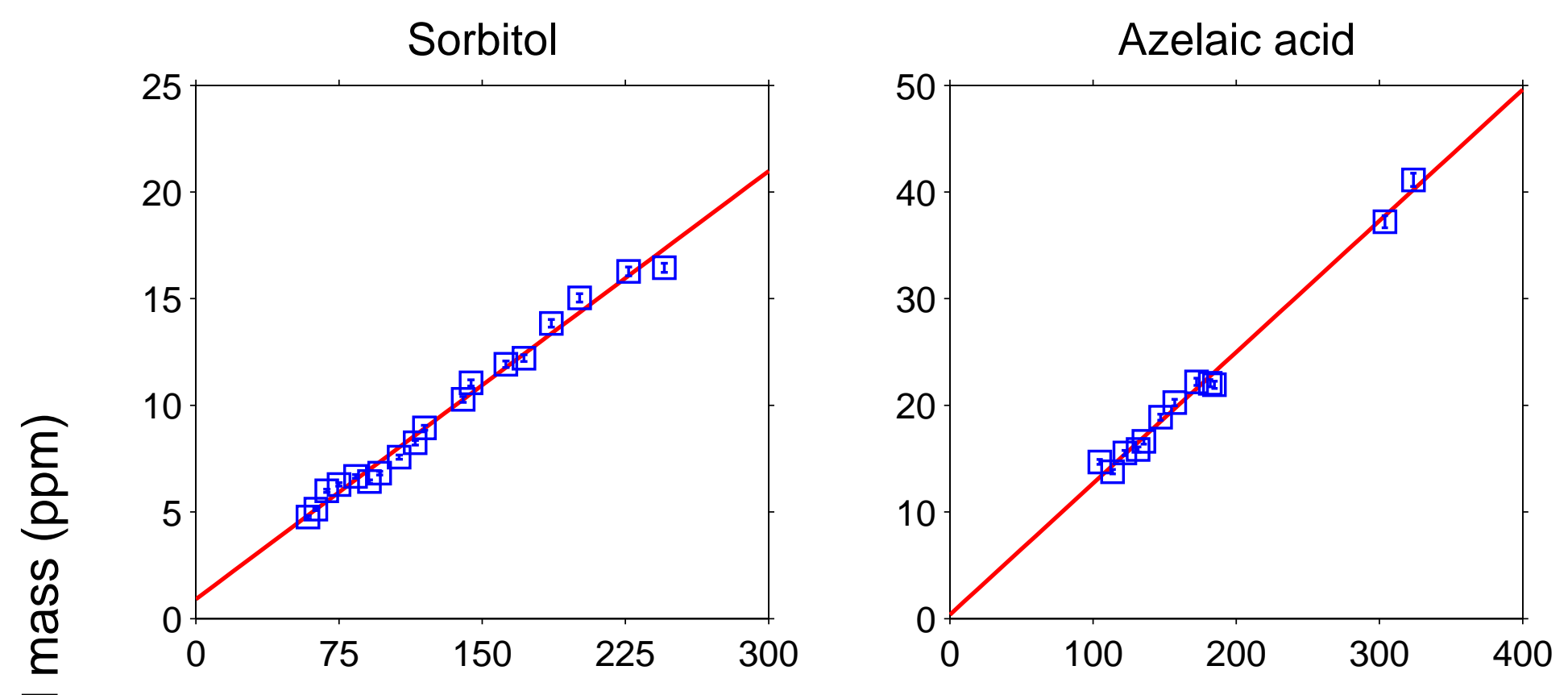

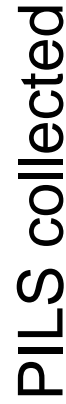
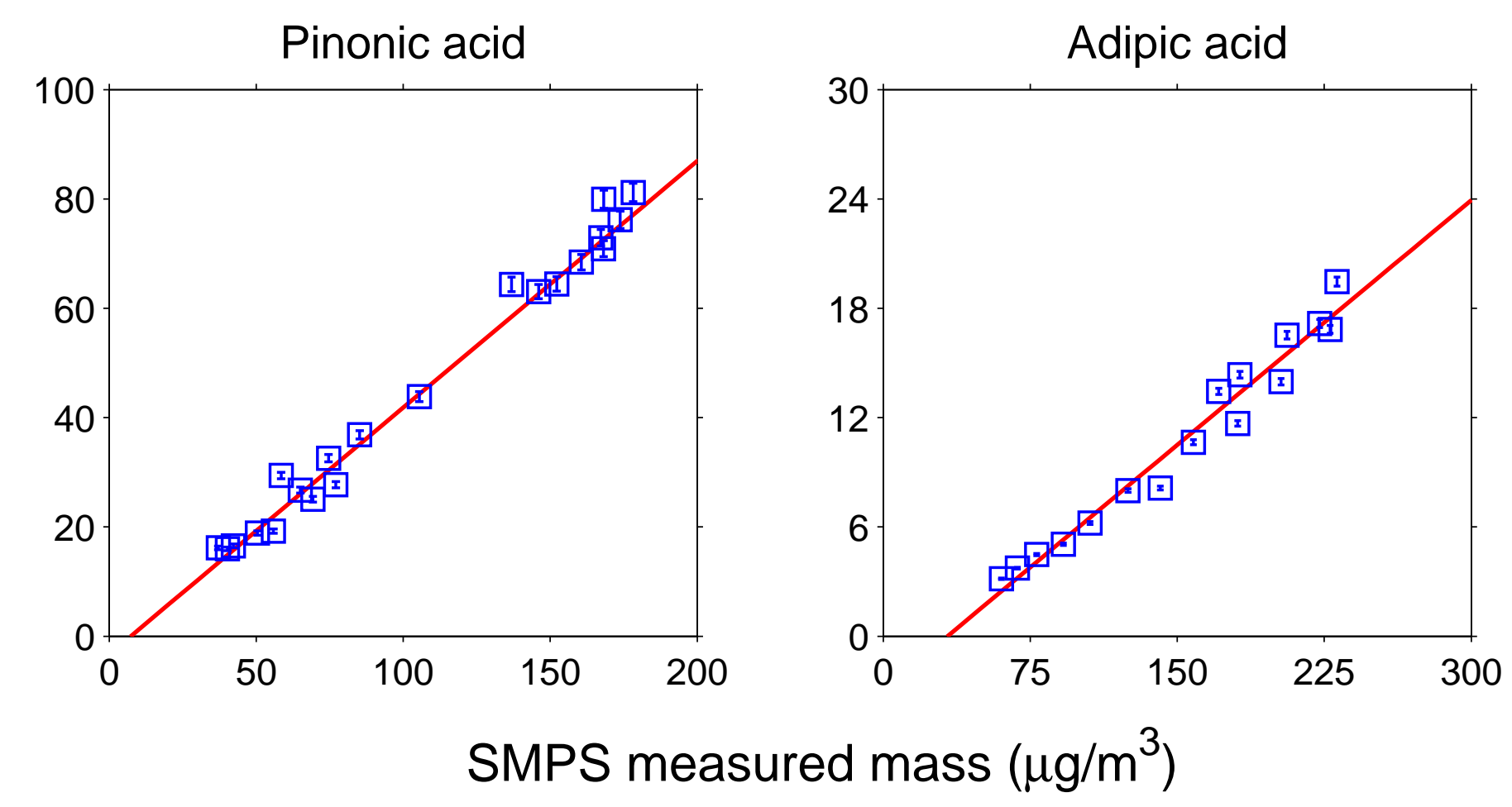

SMPS measured mass $\left(\mu \mathrm{g} / \mathrm{m}^{3}\right)$ 
CIMS and AMS measurement

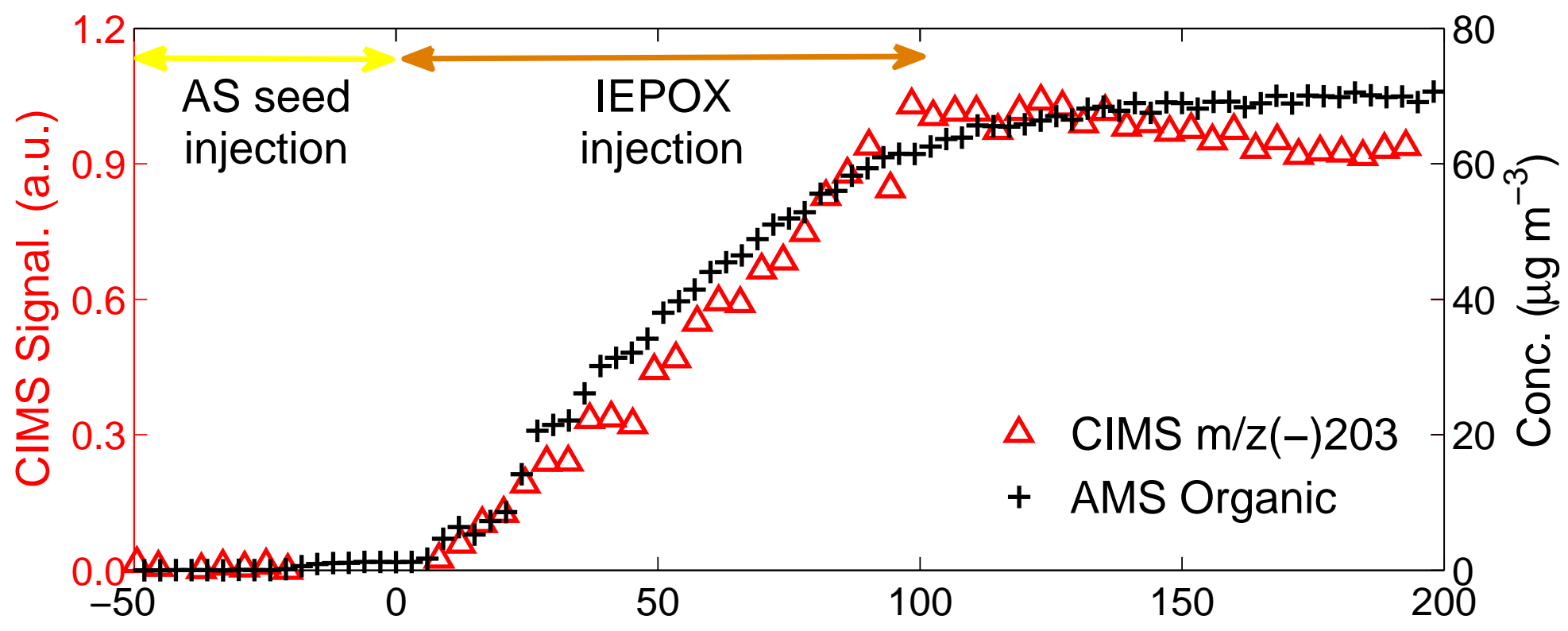

PILS+UPLC/ESI-ToF/MS measurement

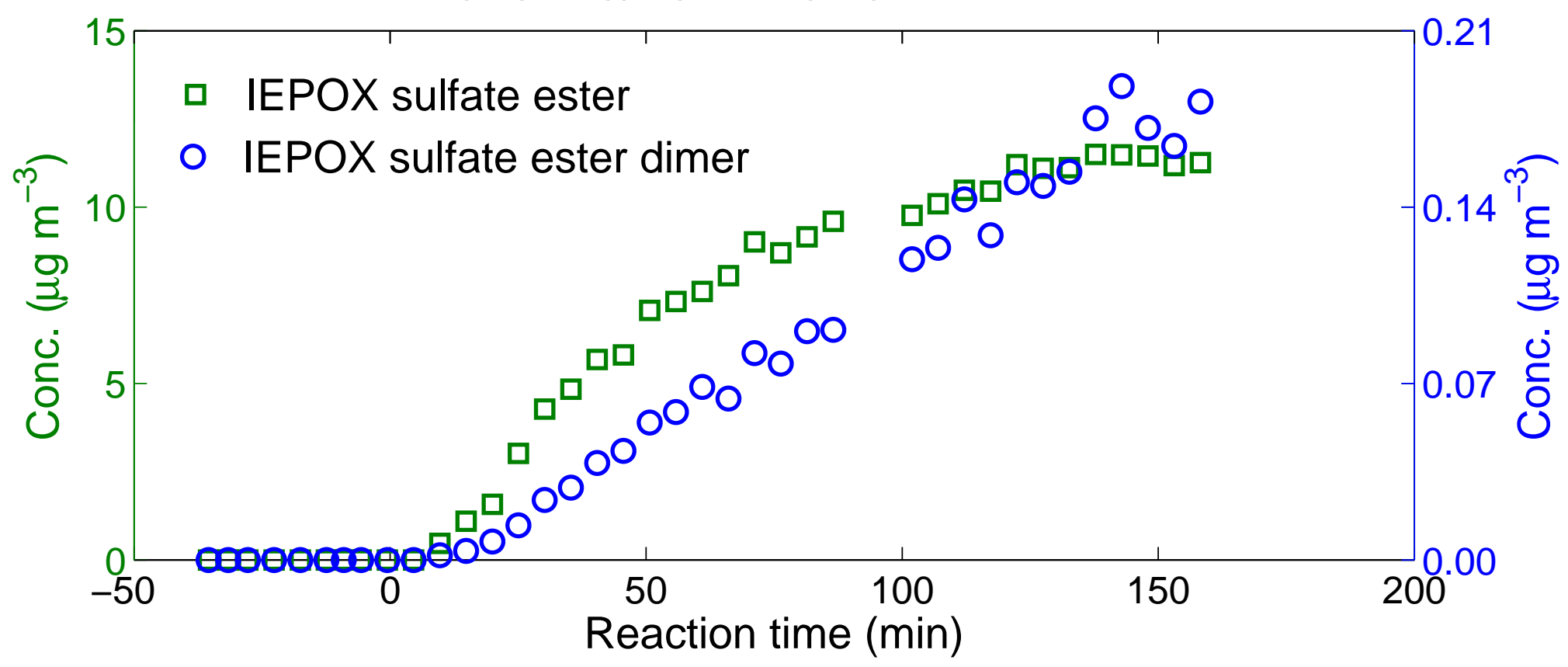



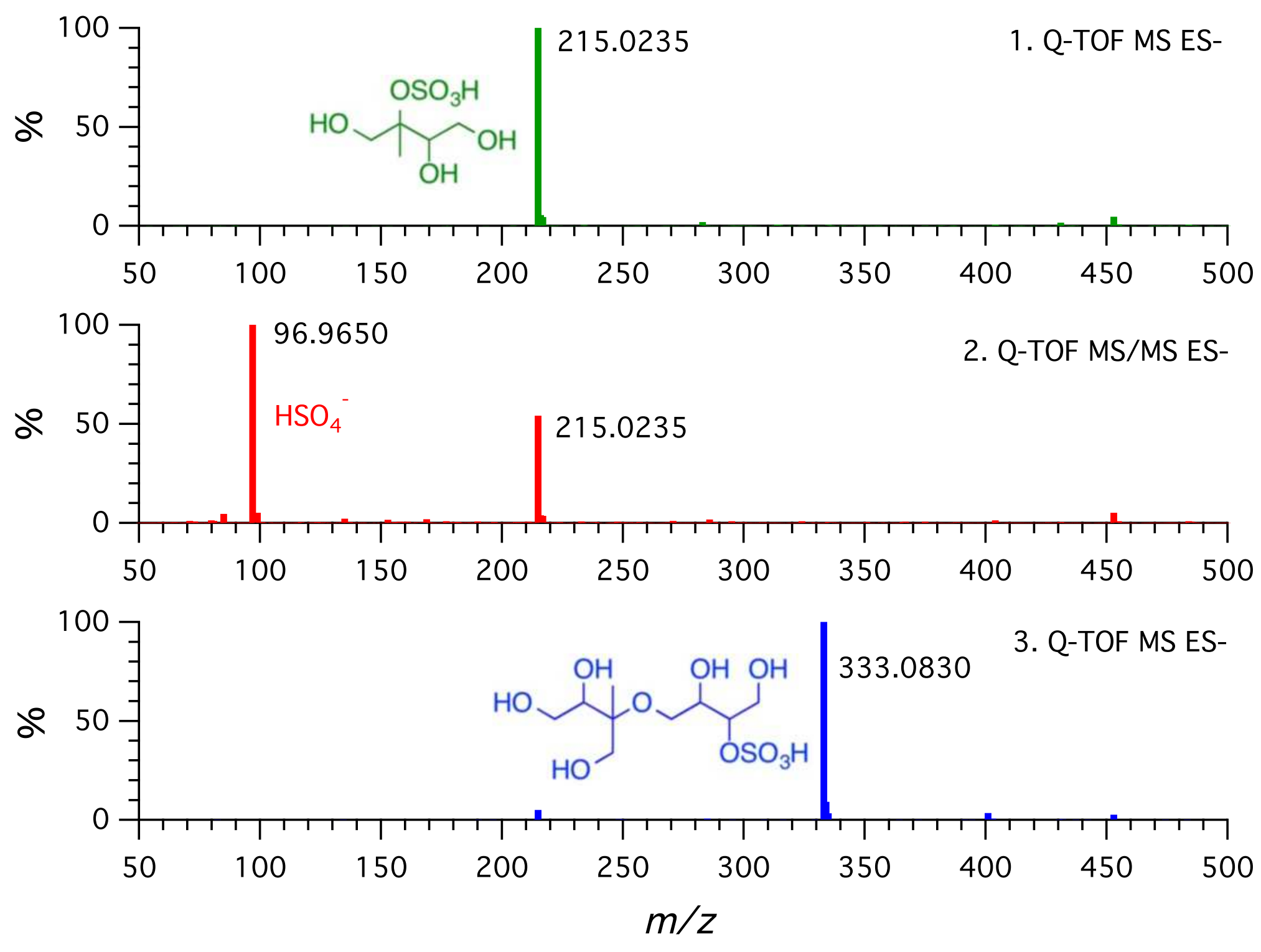